\title{
Why Equal Protection No Longer Protects: The Evolving Forms of Status-Enforcing State Action
}

\author{
Reva Siegel*
}

In this essay, Professor Siegel examines efforts to reform racial and gender status law in the nineteenth century in order to raise questions about the ways antidiscrimination law operates today. The essay demonstrates how efforts to dismantle an entrenched system of status regulation can produce changes in its constitutive rules and rhetoric, transforming the status regime without abolishing it. Part I illustrates this reform dynamic in the nineteenth century, a period when protest movements were demanding the abolition of slavery and reform of marital status law. Legislatures and courts responded by eliminating some of the more overtly hierarchical features of marital status law, yet adopted gender-biased policies governing domestic labor and domestic violence that were justified as promoting family privacy, rather than marital hierarchy. Similarly, in the aftermath of the Civil War, legislatures and courts granted the newly emancipated slaves "civil" rights, yet denied them "social" rights, rationalizing miscegation laws and segregation as preserving associational liberty, rather than racial hierarchy. As these examples illustrate, the rules and reasons the legal system employs to enforce status relationships evolve as they are contested. Part II of the essay uses this dynamic model of status regulation to analyze the operations of equal protection law today. We know that doctrines of heightened scrutiny have disestablished overtly classificatory forms of race and gender status regulation dating from the nineteenth century. Yet the doctrine of discriminatory purpose currently sanctions facially neutral state action that perpetuates race and gender stratification, so long as such regulation is not justified in discredited forms of status-based reasoning. Once we recognize that the rules and reasons the legal system employs to enforce status relations evolve as they are contested, we ought to scrutinize justifications for facially neutral state action with skepticism, knowing that we may be rationalizing practices that perpetuate historic forms of stratification, much as Plessy v. Ferguson once did.

Students in an introductory constitutional law class recently demonstrated for me an unsettling feature of conventional moral judgments about slavery. We were beginning to study the Fourteenth Amendment, and had paused to

* Professor of Law, Yale Law School. I am grateful to the friends and colleagues who commented on this manuscript: Bruce Ackerman, Akhil Amar, Jack Balkin, Mark Barenberg, Hugh Baxter, Lisa Cardyn, Mary Anne Case, Harlon Dalton, Owen Fiss, Sheila Foster, Robert Gordon, Angela Harris, Joel Paul, Robert Post, Tanina Rostain, and participants in faculty workshops at the University of Southem Califormia Law Center and the University of Toronto, Faculty of Law. Many thanks to Tomiko Brown Hall and Ariela Dubler for their research assistance. 
examine provisions of the original Constitution in which the framers sanctioned slavery. Examining the text of the Constitution from this perspective evidently produced unease, and students repeatedly asserted that slavery was morally evil. But when pressed to clarify whether they were suggesting that the framers were evil men, students insisted, with equal certitude, that the framers remained wise forefathers, worthy of our continuing veneration. The class offered a variety of reasons why the framers might have sanctioned slavery: At the time of the founding, prevailing racial mores, values of property, principles of federalism, and the quest for union all provided grounds for sanctioning a morally controversial practice that is now universally condemned.

In short, the moral judgment about slavery that students initially expressed had unarticulated temporal premises. For this group of predominantly white students, practicing or permitting slaveholding in the eighteenth century did not warrant the same kind of moral censure it might today, when the practice is universally condemned. In pronouncing slavery evil, the students were offering a retrospective moral evaluation of the practice. This retrospective judgment in turn afforded little guidance in evaluating contemporary practices. When I asked the class whether there were any social practices currently sanctioned by the Constitution that our descendants might judge evil with the same degree of consensus that characterizes our judgments about slavery, the class could not agree upon one. Instead, students identified a variety of contemporary practices that many Americans condemn as morally abhorrent but other Americans defend on widely accepted grounds. None of these practices elicited the kind of unqualified condemnation that students retrospectively expressed about slavery.

In our constitutional culture, we often express judgments about subordinating practices of the past as if they were timeless truths. Speaking in this tradition, the Supreme Court recently asserted that "we think Plessy was wrong the day it was decided." 1 This manner of speaking about past practices aspires to transcontextual moral certainty; yet precisely as it does so, it obscures distinctions of the sort that the students judged important in their discussion of slavery. As Michael Klarman has most recently reminded us, Plessy was approved by the vast majority of white Americans at the time it was decided; ${ }^{2}$ whatever else might be said about current racial attitudes, most white Americans would now energetically denounce such a decision. ${ }^{3}$ Thus, even if Plessy was wrong

1. Planned Parenthood v. Casey, 505 U.S. 833, 863 (1992) (citing Plessy v. Ferguson, 163 U.S. 537 (1896)).

2. See Michael J. Klarman, Rethinking the Civil Rights and Civil Liberties Revolutions, 82 VA. L. REv. 1, 25-27 (1996).

3. Surveys report that, over the decades, a groving number of whitc Americans have embraced principles of racial equality, although these same surveys document important discrepancies between the egalitarian principles many white Americans espouse and the persisting forms of racial bias that they manifest. For summaries of some of these sociological studies, see A COMMON DESTINY: BLACKS AND AMERICAN SocIETy 119.27 (Gerald David Jaynes \& Robin M. Williams, Jr. eds., 1989) and David Benjamin Oppenheimer, Negligent Discrimination, 141 U. PA. L. Rev. 899, 902-15 (1993). See also Eleanor Marie Brown, Note, The Tower of Babel: Bridging the Divide Between Critical Race Theory and "Mainstream" Civil Rights Scholarship, 105 YALE L.J. 513, 523-29 (1995) (describing studies documenting the discrepancy between white subjects' self-perception and their behavior). 
the day it was decided, the decision was surely wrong in 1896 in a different sense than it would be "wrong" if announced by the Court today.

Why examine the ways in which earlier generations of Americans justified the subordinating practices of their day? Is the point of such an exercise to make excuses for our predecessors? To the contrary: it is to discuss the practices of our predecessors in terms that more deeply implicate us in the present. It is now commonplace to condemn slavery and segregation-a rhetorical practice presumably intended to bind Americans ever more closely to principles of equality. But repeated condemnation of slavery and segregation may have just the opposite effect. We have demonized subordinating practices of the past to such a degree that condemning such practices may instead function to exonerate practices contested in the present, none of which looks so unremittingly "evil" by contrast. That which we retrospectively judge evil was once justified as reasonable. If we reconstruct the grounds on which our predecessors justified subordinating practices of the past, we may be in a better position to evaluate contested practices in the present.

* * * * *

This essay begins from a simple proposition: The ways in which the legal system enforces social stratification are various and evolve over time. Efforts to reform a status regime bring about changes in its rule structure and justificatory rhetoric-a dynamic I have elsewhere called "preservation-through-transformation." 4 In short, status-enforcing state action evolves in form as it is contested.

This, of course, is not the prevailing view in our constitutional culture. Contemporary equal protection law is premised on a formal and historically static conception of "discrimination." Race or sex discrimination occurs when the state regulates on the basis of race- or sex-based classifications; heightened scrutiny of such state action is necessary for the nation to transcend a "history of classification"s - the Court's summary referent for the history of race- and gender-subordinating state action. This concept of classification defines understandings of discrimination, both historical and contemporary. When the state regulates on the basis of "facially neutral" criteria that have injurious effects on minorities or women, the Court presumes the regulation is constitutional and reviews it in a highly deferential manner. ${ }^{6}$ The Court will only strike down such regulation if it is shown to be adopted with discriminatory purpose-a concept the Court has defined as tantamount to malice.?

4. Reva B. Siegel, "The Rule of Love": Wife Beating as Prerogative and Privacy, 105 YALE L.J. 2117, 2178-87 (1996).

5. See Miller v. Johnson, 115 S. Ct. 2475, 2491 (1995) (" "The history of racial classifications in this country suggests that blind judicial deference to legislative or executive pronouncements of necessity has no place in equal protection analysis." (quoting City of Richmond v. J.A. Croson Co., 488 U.S. 469, $501(1989))$ ).

6. See, e.g., Personnel Adm'r v. Feeney, 442 U.S. 256 (1979) (holding that a veterans preference in civil service employment that excluded most women from covered jobs did not violate equal protection); Washington v. Davis, 426 U.S. 229 (1976) (holding that a facially neutral employment test that excluded four times as many black as white applicants did not violate equal protection).

7. See text accompanying notes 104-110 infra. 
Over the last several decades, this body of equal protection doctrine has abolished many traditional forms of race and gender status regulation, and so has transformed the face of the American legal system. But has it ended the state's role in enforcing race and gender stratification-or instead caused such regulation to assume new form? Viewed historically, this question might be recast in the following terms. The body of equal protection law that sanctioned segregation was produced as the legal system endeavored to disestablish slavery; the body of equal protection law we inherit today was produced as the legal system endeavored to disestablish segregation. Are we confident that the body of equal protection law we inherit today is "true" equal protection, or might it stand in relation to segregation as Plessy and its progeny stood in relation to slavery?

So long as we view status law in static and homogenous terms-as we do when we equate "discrimination" with "classification"-it is plausible to imagine ourselves at the end of history, finally and conclusively repudiating centuries of racial and gender inequality. But if we consider the possibility that the kinds of rules and reasons employed to enforce status relationships change as they are contested, then it is possible to see contemporary equal protection law in a different light. In matters of racial and gender inequality, America of the late twentieth century may share more in common with America of the late nineteenth century than at first appears to be the case.

In the first part of this essay, I discuss changes in racial and gender status law during the Reconstruction era in order to illustrate my claim that the kinds of rules and reasons employed to enforce status relationships evolve as they are contested. In the second part of the essay, I then employ this dynamic model of status regulation to raise a series of questions about the operations of equal protection law today.

\section{The Evolving Forms of Status-Enforcing State Action: Some Historical PeRspectives}

For centuries, the Anglo-American common law situated persons in explicitly hierarchical relationships. Thus, the common law organized the "domestic" relations of husband/wife and master/servant as relations of governance and dependence, with the law specifying the rights and obligations of superior and inferior parties. The American common law modeled chattel slavery on this "domestic" analogue as well. ${ }^{8}$

8. See, e.g., Christopher Tomlins, Subordination, Authority, Law: Subjects in Labor History, 47 INT'L LAB. \& WorkING-Class HIST., Spring 1995, at 56, 70 ("The legal commonalities among the domestic relations during the nineteenth century were commonalities of authorized power: of masters/ employers over slaves/servants/apprentices/employees, of husbands over wives, parents over children. They were recognized, deplored, and defended as such."); see also Margaret A. Burnham, An Impossible Marriage: Slave Law and Family Law, 5 LAw \& INEQ. J. 187, 191-95 (1987) (quoting nineteenthcentury courts and commentators who describe slavery as a family, household, or domestic relation); Emily Field Van Tassel, "Only the Law Would Rule Between Us": Antimiscegenation, the Moral Economy of Dependency, and the Debate Over Rights After the Civil War, 70 CH.-KENT L. REv. 873, 880-90 (1995) (same). 
It is conventionally asserted that status law of this sort died out with the growth of capitalism and the spread of liberal conceptions of citizenship. Various accounts of modernization posit a movement during the nineteenth century from "status to contract," resulting in the break up of status hierarchies and the redefinition of juridical persons as equal in capacity and entitlement. ${ }^{9}$

These traditional assumptions about the form and developmental trajectory of status law do not bear up well under historical scrutiny. Rogers Smith is now writing a treatise that meticulously documents race- and gender-based features of American citizenship law as it evolved over a period extending from the Founding to the Progressive era. ${ }^{10}$ Smith argues that American political development needs to be understood in terms of the interaction of three traditions: liberalism, republicanism, and a third tradition that he denominates "inegalitarian ascriptive."11 Similarly, a number of labor historians have begun to demonstrate ways in which the old hierarchical forms of master/servant law shaped the body of contract law that was developed to regulate employment relationships in the nineteenth century. ${ }^{12}$ A large body of scholarship documents the evolution of racial status law in the transition from slavery to segregation. ${ }^{13}$ And, as I will discuss in more detail below, my own work on marriage law during the Reconstruction era demonstrates how nineteenth-century reform of the old common law coverture rules translated the status relationship of husband/wife into new juridical forms.

There is no doubt that by the second half of the nineteenth century the American legal system began to address the old status relations of the common law in new ways. In this period, the legal system began to eschew overt relations of hierarchy, and to assert the juridical equality of persons formerly re-

9. See Robert W. Gordon, The Past as Authority and as Social Critic: Stabilizing and Destabilizing Functions of History in Legal Argument, in THE HISTORIC TURN IN the HUMAN SCIENCES 339, 347-49 (Terrence J. McDonald ed., 1996) (discussing "the core narrative of liberal progress" in recent American histories of law); see also Reva B. Siegel, The Modernization of Marital Status Law: Adjudicating Wives' Rights to Earnings, 1860-1930, 82 GEO. L.J. 2127, 2133-34, 2139-40 (1994) (describing and criticizing the status-to-contract narrative traditionally employed to explain the reform of marriage law).

10. Rogers M. Smith, Civic Ideals: Conflicting Visions of Citizenship in U.S. Public Law (unpublished manuscript, on file with the author).

11. Id. at 8 .

12. See Karen Orren, Belated Feudalism: Labor, the Law, and Liberal Development in the United States (1991); Robert J. Steinfeld, The InVEntion of Free Labor: The Employment Relation in English and American Law and Culture, 1350-1870 (1991); Christopher L. TOMLINS, LAW, LABOR, AND IDEOLOGY IN THE EARLY AMERICAN REPUBLIC 259-61 (1993); Tomlins, supra note 8.

13. See, e.g., JAmes D. ANderson, The Education of Blacks IN THE South, 1860-1935, at 14885 (1988) (describing development of segregated and unequal school systems after emancipation); JoHN HOPE FRANKLIN, RECONSTRUCTION: AFTER THE CIVIL WAR 201-02 (1961) (discussing undermining of black voting rights after passage of Reconstruction amendments); GERALD JAYNES, BRANCHES WITHOUT ROOTS: GENESIS OF THE BLACK WORKING CLASS IN THE AMERICAN SOUTH, 1862-1882, at 301-16 (1986) (discussing the use of criminal law, crop lien systems, and judicial enforcement of dubious labor contracts to control the labor of emancipated slaves); Daniel A. Novak, The Wheel of Servitude: BLACK FORCED LABOR AFTER SLAVERY 44-62 (1978) (discussing ways that southern state legislatures eluded antipeonage norms imposed by federal courts). See generally ERIC FONER, RECONSTRUCTION: AMERICA's UNFINISHED REVOLUTION, 1863-1877 (1988) (analyzing struggles over the direction and extent of racial reform during Reconstruction). 
lated in hierarchical terms. But as one begins to scrutinize particular bodies of nineteenth-century law, it becomes clear that such changes did not eradicate foundational status structures: In gender, race, and class relationships, the legal system continued to allocate privileges and entitlements in a manner that perpetuated former systems of express hierarchy. Analyzed from this vantage point, the rise of liberal and capitalist systems of social organization did not result in the dismantlement of status relationships, but instead precipitated their evolution into new forms.

This process of transformation is well worth examining. In the middle decades of the nineteenth century, the American legal system sought, as it never had before, to repudiate bodies of law that for centuries had defined AfricanAmericans and white women as subordinate members of the polity. That this effort to disestablish entrenched bodies of status law was fitfully pursued, energetically resisted, and soon abandoned does not detract from its significance. For in this period of sweeping sociolegal change, we can examine the disestablishment dynamic as it actually unfolds in history. In the tug and haul of politics, the process of dismantling an entrenched system of status relations may well transform the regime without abolishing it.

\section{A. Marital Status Law}

Consider the case of marriage law, which I have been studying for some years now. At the opening of the nineteenth century, the common law organized marriage as a hierarchical relationship of governance and dependence. The law gave a husband rights in his wife's person, labor, and property, and then imposed upon him a duty to support his wife and to represent her in the legal system. A wife was correspondingly expected to submit to her husband and serve him. The common law not only deprived a married woman of rights in her labor and property, but denied her the capacity to bring suits or enter contracts without her husband's consent and participation. ${ }^{14}$

A variety of socioeconomic forces led to the incremental reform of this body of status law over the course of the nineteenth century. The most prominent of these was a nascent woman's rights movement, which grew out of abolitionist and temperance groups of the era. By the 1850s, woman's rights activists were meeting in national and regional conventions and circulating legislative petitions to protest the common law of marriage, dramatizing the many ways in which its hierarchical structures violated tenets of liberalism and norms of companionate marriage. ${ }^{15}$ Responding to these demands for autonomy and equality in marriage, state legislatures slowly began to modify the common law doctrines of coverture. Statutes enacted in the years before the Civil War, and

14. For a general overview of common law and equitable principles governing marital status in the antebellum period, see Norma BASCH, IN THE EYes OF THE LAW: WOMEN, MARRIAGE, AND PROPERTY in Nineteenth-Century New York 47-55, 70-112 (1982).

15. See id. at 162-99 (examining woman's rights campaign in New York, culminating in the passage of a prominent 1860 marital property reform statute); Reva B. Siegel, Home As Work: The First Woman's Rights Claims Concerning Wives' Household Labor, 1850-1880, 103 YALE L.J. 1073, 1098146 (1994) (examining the movement's efforts in the antebellum era to enact joint property laws that would give wives rights in their household labor). 
then for decades after, recognized a woman's right to hold property in marriage and granted wives rights in their earnings, as well as the rudiments of legal agency. By the century's end, the cumulative effect of these statutes was to give wives in many states the ability to engage in a variety of third-party transactions without the impediment of marriage. ${ }^{16}$

It was now more likely that a married woman could hold property in her own name, claim wages as her own, and bring suit over a contract or tort claim as if she were single. ${ }^{17}$ Yet, in all states, the common law still disabled a wife from dealing with her husband on such terms. A wife who worked for third parties could, in many circumstances, claim and recover wages in her own right. But if she worked in the family household, farm, or business setting (as most wives did), she could not make an enforceable agreement with her husband for compensation. ${ }^{18}$ Many of the statutes granting wives rights in their earnings expressly excluded the labor that a wife performed for her husband or children, and where statutes were silent about the matter, courts construed them to exempt such work. ${ }^{19}$ The value of this labor remained a husband's by marital right. Similarly, a wife of the late nineteenth century was often able to sue third parties for injuries to her person and property. But she could not sue a husband who assaulted or battered her. No statute granting married women the capacity to bring suits in tort contained such an exemption, but all courts that considered the question in the late nineteenth century construed the statutes to bar such suits. ${ }^{20}$ The courts that devised the doctrine of interspousal tort immunity to contain the more radical implications of the marriage reform statutes were of the unanimous opinion that a husband no longer had the common law right to inflict corporal punishment on his wife, ${ }^{21}$ but these courts were equally confident that the law could not countenance a wife's hauling her husband into court to adjudicate questions of spousal violence.

Decades of woman's rights advocacy had changed the legal structure of the marriage relationship. Married women had acquired many rights that the common law originally denied them, yet they still lacked ordinary forms of legal recourse in a relationship that typically dominated their lives. As we will see, the legal system justified these anomalies in the juridical capacity of married

16. See, e.g., Siegel, supra note 9, at $2149-68$ (surveying reform in nineteenth-century New York); see also sources cited in note 17 infra (discussing reform in other jurisdictions).

17. See, e.g., Richard H. Chused, Late Nineteenth Century Married Women's Property Law: Reception of the Early Married Women's Property Acts by Courts and Legislatures, 29 AM. J. LEGAI HIST. 3, 3-5 (1985); David Stewart, Contracts of Married Women Under Statutes, 19 AM. L. Rev. 359, 364-70 (1885). See generally Joseph Warren, Husband's Rights to Wife's Services (pts. 1-2), 38 HaRv. L. Rev. 421.622 (1925) (providing an overview of such legislation as of 1925). Generalizing about these developments is difficult because of the variety of state reform statutes and the diverse ways in which courts interpreted them.

18. See Siegel, supra note 9 , at 2168-96.

19. See Siegel, supra note 15 , at 1180-87. In restricting the scope of the earnings statutes, legislatures and courts were repudiating demands of the woman's rights movement for reforms that would give wives property rights in their household labor. See id. at 1112-88 (documenting movement demands for joint property rights in marriage, and demonstrating how this rights discourse challenged common law and customary norms that gave husbands rights to the value to their wives' household labor).

20. See Siegel, supra note 4, at 2161-66.

21. See id.; $c f . i d$. at 2129-30 (describing judicial repudiation of the right to chastisement). 
women in a new language of "public policy" that drew upon the gendered understandings of industrial America to explain the structure of marriage in ways that the traditional, authority-based discourse of the common law no longer could.

At the opening of the nineteenth century the law structured marriage as a relationship of mastery and subordination in which a wife's identity "merged" into her husband's, but, by the close of the century, legislatures, judges, and jurists were notably uncomfortable invoking the language of mastery and submission to justify the structure of the relationship. Far less frequently did courts assert that a husband had authority over his wife or property rights in her services. Instead, as courts struggled to explain why a married woman had the capacity to deal with third parties but lacked ordinary forms of legal recourse against her husband, judges invoked nineteenth-century conceptions of domesticity and companionate marriage to justify the relationship of husband and wife in new terms. ${ }^{22}$

In this emergent account, marriage was an affective relation that subsisted and flourished in a private domain beyond the reach of law. A wife could not enforce a contract with her husband compensating her for work performed in the family sphere because such labor was to be performed altruistically, rather than self-interestedly: for love, not pay. ${ }^{23} \mathrm{~A}$ wife could not bring a tort claim against a husband who battered her because such conflicts were to be resolved altruistically, by marital partners who would, or should, learn to forgive and forget. ${ }^{24}$ Adjudication of intramarital contract or tort claims, courts reasoned, would destroy marital harmony and expose private aspects of the conjugal relation to the corrosive glare of public scrutiny. ${ }^{25}$ Thus, with the reform of marital status law, the discourse of marital status began to shift from the language of hierarchy to the language of interiority. By the turn of the century, courts seeking to justify wives' continuing legal disabilities described marriage as an emotional relationship subsisting in a private realm "beyond" the reach of lawreasoning about the relationship in these terms would have startled Blackstone.

These changes in the rules and rhetoric of marital status law considerably enhanced its authority. Legislatures and courts could now, with some justification, declare that married women had been granted equality with their husbands. Wives still had no rights to the economic value of labor they performed for their families, nor could they take action against (or expect action against) husbands who beat them, but these were consequences of reasonable public policies having nothing to do with the subordination of women at law. (The same could be said of new forms of legislation regulating women's birth control practices and employment that were enacted in this era. ${ }^{26}$ ) Such policies

22. See Siegel, supra note 9 , at 2199-206.

23. See id.

24. See Siegel, supra note 4 , at 2161-66.

25. See id. at $2166-70$.

26. See Reva Siegel, Reasoning from the Body: A Historical Perspective on Abortion Regulation and Questions of Equal Protection, 44 STAN. L. REv. 261, 319-23 (1992) (describing how new forms of regulation that criminalized birth control practices and restricted women's employment were justified on physiological grounds). 
were reasonable because they explained the marriage relationship in terms that accorded with the understandings of nineteenth-century Americans, re-presenting wives' legal disabilities in the equality-inflected idiom of companionate marriage.

In short, the effort to disestablish the common law of marital status transformed its structure and translated its justifications into a more contemporary gender idiom-a reform dynamic I call "preservation-through-transformation." 27 As the case of marital status law illustrates, attempts to dismantle a status regime can discredit the rules and reasons employed to enforce status relations in a given historical era, and so create pressure for legislators and jurists to reform the contested body of law enough so that it can be differentiated from its contested predecessor. Assuming that something of value is at stake in such a struggle, it is highly unlikely that the regime that emerges from reform will redistribute material and dignitary "goods" in a manner that significantly disadvantages the beneficiaries of the prior, contested regime. But if the reformed body of law is to reestablish its legitimacy, it must distribute social goods in a manner that can be differentiated from the prior, contested regime. Thus, lawmakers seeking to reestablish the legitimacy of a contested body of status law will begin to revise its constitutive rules, and to justify the new body of law without overt recourse to the justificatory discourse of the prior, contested regime. In this way, the effort to disestablish a body of status law can produce changes that modernize its rule structure and justificatory rhetoric. These reforms may well improve the material and dignitary circumstances of subordinated groups, but they will also enhance the legal system's capacity to justify regulation that perpetuates inequalities among status-differentiated groups. Analyzed from this vantage point, status-enforcing state action has no fixed or transhistorical form, but instead evolves in rule structure and justificatory rhetoric as it is contested.

\section{B. Racial Status Law}

The concept of preservation-through-transformation provides a framework for thinking about the evolution of racial status law during the Reconstruction era. The regime of segregation sanctioned in Plessy was, after all, the result of efforts to disestablish slavery. Though today we tend to think about the transition from slavery to segregation as a seamless episode of invidious racial classification, white Americans in the nineteenth century viewed the changes in racial status law of their day in very different terms: as elevating AfricanAmericans from subordination in slavery to equality at law. In the nineteenth century, at a time when the state still openly drew distinctions in the rights and disabilities of diverse groups of citizens, equality at law was an ill-defined concept, fraught with contradictions and subject to contestation.

White Americans who emphatically opposed slavery regularly disagreed about what it would mean to emancipate African-Americans. Some defined freedom from slavery as equality in civil rights; others insisted that emancipat-

27. See Siegel, supra note 4, at 2178-88. 
ing African-Americans from slavery entailed equality in civil and political rights; but most white Americans who opposed slavery did not think its abolition required giving African-Americans equality in "social rights."28 Distinctions among civil, political, and social rights functioned more as a framework for debate than a conceptual scheme of any legal precision. But it was generally understood that civil rights were those rights exercised by economic man, such as the capacity to hold property and enter into contracts, and to bring suit to defend those rights in the legal system. ${ }^{29}$ Voting was the core political right. ${ }^{30}$ Social rights were those forms of association that, white Americans feared, would obliterate status distinctions and result in the "amalgamation" of the races. ${ }^{31}$

White Americans reasoning about the fate of the emancipated slaves drew such distinctions precisely because their commitment to abolish slavery was not a commitment to recognize African-Americans as equals in all spheres of social life; in the years before and after the Civil War, white Americans of widely varying political views reiterated their conviction that emancipating AfricanAmericans entailed granting the freedmen some form of legal equality, but assuredly did not require granting them "social equality." 32 Abolishing slavery thus entailed a struggle over the shape of racial status law, one that would ultimately transform its rule structure and justificatory rhetoric. The triadic distinction among civil, political, and social rights created a discursive field in which we can see the dynamic of preservation-through-transformation at work.

28. On the distinctions among civil, political, and social rights, see HAROLD M. HYMAN \& WILliam M. Wiecek, Equal Justice Under Law: Constitutional Development, 1835-1875, at 299 300, 395-97 (1982); Michael W. McConnell, Originalism and the Desegregation Decisions, 81 VA. L. REv. 947, 1014-23 (1995); Joseph William Singer, No Right to Exclude: Public Accommodations and Private Property, 90 Nw. U. L. Rev. 1283, 1349-50 (1996); Mark Tushnet, The Politics of Equality in Constitutional Law: The Equal Protection Clause, Dr. Du Bois, and Charles Hamilton Houston, $74 \mathrm{~J}$. Aм. Hist. 884, 886-90 (1987).

For a discussion of the distinction between civil and political rights as it applied to matters conceming women's status, see Akhil Reed Amar, The Bill of Rights: Creation and Reconstruction 301 (1997) (unpublished manuscript, on file with author) (during the Reconstruction era, the "unmarried white woman in many ways defined the basic legal category of 'civil' as opposed to 'political' rights"); Nina Morais, Note, Sex Discrimination and the Fourteenth Amendment: Lost History, 97 YALE L.J. 1153, 1157-58 (1988) (construing the Fourteenth Amendment as governing women's civil, but not political, rights).

29. Over the course of Reconstruction, as the Republican Party attempted to expand civil rights protection for the emancipated slaves, the content of the civil rights concept was hotly contested. See, e.g., Robert J. Kaczorowski, Revolutionary Constitutionalism in the Era of the Civil War and Reconstruction, 61 N.Y.U. L. Rev. 863, 922-35 (1986); McConnell, supra note 28, at 1014-43; Tushnet, supra note 28 , at $886-87$.

30. Political rights were often said to include voting, office holding, jury service, and militia service. See Amar, supra note 28 , at 62,301 . On treatment of jury participation as a civil or political right, see id. at 312-14; see also Tushnet, supra note 28, at 887 (discussing Reconstruction controversies over which rights, other than voting, were "political").

31. See Tushnet, supra note 28 , at 886-87.

32. Objections to granting freedmen "social equality" appear throughout the debate on emancipation, before and after the Civil War. For an especially detailed catalogue of "social equality" rhetoric in congressional debate, see Alfred Avins, Social Equality and the Fourteenth Amendment: The Original Understanding, 4 Hous. L. REv. 640 (1967). Those who supported and opposed civil rights reform asserted that equality in social status could not be legislated, but opponents of reform transformed this descriptive claim into a normative argument-objecting to various civil rights measures on the grounds that the legislation would impermissibly promote social equality between the races. 
From this perspective, the successive waves of federal legislation enacted in the aftermath of the Civil War make conceptual sense. When southern states adopted Black Codes constricting land ownership and employment of freedmen in such a way as to tie the emancipated slaves to their former owners, ${ }^{33}$ Congress passed the 1866 Civil Rights Act, providing that:

[c]itizens of every race ... shall have the same right ... to make and enforce contracts, to sue, be parties, and give evidence, to inherit, purchase, lease, sell, hold, and convey real and personal property, and to full and equal benefit of all laws and proceedings for the security of person and property, as is enjoyed by white citizens, and shall be subject to like punishment." 34

Because there was dispute about whether the Thirteenth Amendment's prohibition of slavery vested Congress with the power to define and protect civil rights in this fashion, Congress began work on the drafting and ratification of the Fourteenth Amendment, ${ }^{35}$ and soon thereafter reinacted the substance of the 1866 statute in the Civil Rights Act of $1870 . .^{36}$ When similar disputes arose over scope of rights protected by the Fourteenth Amendment, Congress vested the emancipated slaves with the political right of voting through the Fifteenth Amendment. ${ }^{37}$

As white Americans argued about the kinds of reform that would be required to disestablish slavery, their conflicts were expressed in struggles over constitutional amendments and various pieces of civil rights legislation, as well as in debates about their interpretation. These disputes in turn progressively reshaped the rules and rhetoric of racial status law. While we might trace this dynamic in a number of fields, voting prominent among them, ${ }^{38}$ the ensuing discussion will briefly consider conflicts in the domain of marriage and public transportation, where disputes about the permissibility of racial status regulation were expressed in the form of a debate about the distinction between "civil" and "social" rights.

In the aftermath of the war, when states moved to enact or enforce legislation barring interracial marriage, the question immediately arose: Was marriage a contract protected by the 1866 Civil Rights Act? As opponents of the 1866 Act had feared, ${ }^{39}$ a few courts initially ruled that it was. ${ }^{40}$ But other

33. See, e.g., Leon F. Litwack, Been in the Storm So Long: The Aftermath of Slavery 366-71, 375 (1979); NovaK, supra note 13, at 1-8.

34. Act of Apr. 9, 1866, ch. 31, §1, 14 Stat. 27 (current version at 42 U.S.C. $\S \S 1981,1982$ (1996)).

35. See Kaczorowski, supra note 29, at 910-11; McConnell, supra note 28, at 958.

36. See Act of May 31, 1870, ch. 114, § 18, 16 Stat. 140, 144.

37. See William E. Neison, The Fourteenth Amendment: From Poltitcai Principle to JudiCIAL DOCTRINe 126-27 (1988) (discussing contemporary debates about whether Fourteenth Amendment applied to political or only civil rights).

38. See notes 71-72 infra and accompanying text.

39. See McConnell, supra note 28 , at 959 (noting that opponents of the civil rights bill "warned of different perils, a favorite being that the bill would forbid antimiscegenation statutes"). In vetoing the 1866 Act, President Johnson also objected that it would involve the federal government in regulating marriage. See Cong. GloBE, 39th Cong., 1st Sess. 1679, 1680 (1866).

40. See Burns v. State, 48 Ala. 195 (1872) (reversing the conviction of a justice of the peace who married an interracial couple), overruled by Green v. State, 58 Ala. 190, 197 (1877); Hart v. Hart, 26 La. Ann. 90 (1874) (recognizing interracial marriage for purposes of settling an inheritance dispute). Com- 
courts moved rapidly to restrict the meaning of the federal statute, by construing its antidiscrimination provision to apply to contracts involving "civil" rather than "social" rights. In this view, the right to marry was a "social right," not governed by the federal law.

Taking the lead, the North Carolina Supreme Court deftly recharacterized the ambit of the 1866 Civil Rights Act:

Its object was, and its terms are, to declare equality between all citizens without regard to race or color, in the matters of making business contracts, suing in the courts, giving evidence, acquiring property and in the protection of person and property.... But neither the Civil Rights Bill nor our State Constitution was intended to enforce social equality, but only civil and political rights. This is plain from their very terms. But if the terms were doubtful, the policy of prohibiting the intermarriage of the two races is so well established and the wishes of both races so well known that we should not hesitate to declare the policy paramount to any doubtful construction. ${ }^{41}$

Asking whether federal law had "elevated [the African] to a perfect equality in social, as well as political, rights with the Caucasian," 42 the Tennessee Supreme Court ruled it had not, again reasoning that marriage was not a contract within the meaning of the Civil Rights Bill or the Constitution. Marriage was a "civil status," not a contract. "Although it may be formed by a contract, yet when formed, it has none of the attributes of a contract, but becomes a domestic relation. ... ' $[I]$ t is no more a contract than a fatherhood, or a sonship, or a serfdom, or slavery, or apprenticeship, are contracts." 43 The Alabama Supreme Court thereafter followed suit, upholding a law prohibiting interracial marriage on the grounds that " $[t]$ he amendments to the Constitution were evidently designed to secure to citizens, without distinction of race, rights of a civil or political kind only-not such as are merely social, much less those of a purely domestic nature. The regulation of these belongs to the States." 44 (Elaborating on the "domestic nature" of the marriage relation, the Alabama

pare State v. Webb, 4 CENT. L.J. 588 (1877) (striking down Texas miscegenation statute as part of legacy of slavery) with Frasher v. State, 3 Tex. Ct. App. 263, 277 (1877) (finding the Texas statute valid).

41. State v. Hairston, 63 N.C. 439,441 (1869) (per curiam) (emphasis added). That same year, the Georgia Supreme Court interpreted its state constitution along similar lines:

Government has full power to regulate civil and political rights, and to give to each citizen of the State, as our Code has done, equal civil, and equal political rights as well as equal protection of the laws. But Government has no power to regulate social status. Before the laws, the Code of Georgia makes all citizens equal, without regard to race or color. But it does not create, nor does any law of the State attempt to enforce, moral or social equality between the different races or citizens of the State. Such equality does not in fact exist, and never can. The God of nature made it otherwise, and no human law can produce it, and no human tribunal can enforce it.

Scott v. Georgia, $39 \mathrm{Ga} .321,326$ (1869) (upholding law prohibiting interracial marriage).

42. Doc. Lonas v. State, 50 Tenn. (3 Heisk.) 287, 306 (1871).

43. Id. at 308-09 (quoting 1 Bish. MAR. \& Drv. 10).

44. Green, 58 Ala. at 196; see also Francois v. State, 9 Tex. Ct. App. 144, 146 (1880) (asserting that "the several States of the Union, in the adoption of the recent amendments to the Constitution of the United States, designed to secure to citizens rights of a civil or political nature only, and did not part with their hitherto unquestioned power of regulating, within their own borders, matters of purely social and domestic concern). 
court defined the home as a private sphere with whose "interior administration, the State should interfere but a little," 45 even as the court deployed the social rights concept to defend the state's prerogative to regulate marriage without federal interference.) Courts upholding antimiscegenation statutes relied upon the distinction between civil and social rights until they were confident enough-which they were not initially-simply to assert that regulating marriage lay beyond the scope of federal power. ${ }^{46}$

Disputes over the legality of miscegenation laws illustrated that distinctions between civil and social rights were not fixed, but instead were forged in the struggle over the scope of Reconstruction legislation. This dynamic is especially evident in disputes over the legality of segregation in transportation and accommodations. When Republicans in Congress first attempted to enact antidiscrimination legislation to cover common carriers and public accommodations, they asserted that longstanding common law traditions made equal access to such institutions a basic civil right. ${ }^{47}$ But the initial bill addressing these matters also covered schools, churches, cemeteries, theaters, and other institu-

45. The Alabama court reasoned that "[i]t is through the marriage relation that the homes of a people are created" and "[t]hese homes ... are the ... nurseries of States. ... While with their interior administration, the State should interfere but little, it is obviously of the highest public concern that it should, by general laws adapted to the state of things around them, guard them against disturbances from without." Green, 58 Ala. at 194.

During the Reconstruction era, discourses of privacy slowly began to supplant discourses of hierarchy in both racial and gender status law. See Siegel, supra note 4, at 2150-70, 2175-77. In marital status law, courts invoked discourses of the private to explain why married persons were exempt from common law regulation (e.g. interspousal contract or tort claims). See text accompanying notes 23-25 supra. In racial status law, courts invoked discourses of the private to explain why marriage was exempt from federal antidiscrimination regulation. But, in this context, racial discourses of the private functioned to justify the state's prerogative to regulate marriage, and so were in tension with gendered discourses of the private that suggested that marriage was a relation "beyond" the reach of law. In Green, the Alabama Supreme Court dealt with this apparent conflict by suggesting that the state should generally not "interfere" with the "interior administration" of the home, but only "guard [the home against] disturbances from without." Green, 58 Ala. at 194.

46. For an early and quite tentative statement of the federalism argument, see In re Hobbs, $12 \mathrm{~F}$. Cas. 262, 264 (N.D. Ga. 1871) (No. 6550) ("The marriage relation ... has hitherto been regulated and controlled by each state within its own territorial limits, and I cannot think it was intended to be restrained by the amendment, so long as the state marriage regulations do not deny to the citizen the equal protection of the laws. Nor do I think that the state law operates unequally ....") (emphasis added). The Indiana Supreme Court soon thereafter authored an opinion asserting unequivocally that the federal government could not regulate marriage. See State v. Gibson, 36 Ind. 389, $402-03$ (1873). The opinion is expressly premised on the view that the Reconstruction Amendments did not alter the scope of federal power. See id. at 393 ("The fourteenth amendment contains no new grant of power from the people ... to the federal government. It did not enlarge the powers of the federal govemment, nor diminish those of the states."). Courts thereafter invoked Gibson's argument that the federal government could not regulate marriage as a basis for upholding antimiscegenation statutes under federal antidiscrimination law. See, e.g., State v. Jackson, 80 Mo. 175, 178 (1883); Frasher v. State, 3 Tex. Ct. App. 263, 274-75 (1877).

In Pace v. Alabama, 106 U.S. 583 (1882), the Supreme Court upheld, against equal protection challenge, an Alabama law punishing interracial cohabitation more severely than same-race adultery or fornication on the grounds that "[t]he punishment of each offending person, whether white or black, is the same." Id. at 585. The Court's disposition of the Pace case gave authoritative weight to the argument that antimiscegenation statutes treated the races "equally," and this offered yet another ground on which to uphold antimiscegenation statutes under federal law.

47. See McConnell, supra note 28, at 1029-36. 
tions, ${ }^{48}$ and elicited vehement and continuing objections that Congress was attempting to regulate private associations and thereby to legislate social equality. ${ }^{49}$ When Congress finally enacted a much narrower version of the statute in the Civil Rights Act of 1875,50 which prohibited race discrimination in public transportation, accommodations, and theaters, the charge that Congress was impermissibly regulating social rights continued to inform the statute's interpretation and application. As historians have demonstrated, courts generally construed the federal statute to forbid race-based exclusions from covered institutions, but to allow segregation so long as blacks were provided substantially equal facilities with whites. ${ }^{51}$

In rationalizing this result, courts invoked social rights discourse. As one court put it, the 1875 Act did not intend "to affect social rights through civil and legal rights." 52 Another court adopting this interpretation of the Act justified it on the grounds that segregation in the covered institutions was necessary to preserve status relations of inequality which originated in slavery:

The colored men were formerly slaves, and the condition of servitude rendered them greatly wanting in education, refinement and social culture. White men often came in contact with colored men, but the association was that of superiors with inferiors. Before the war, white men who associated with colored men on terms of social equality became degraded in the eyes of the community. These social prejudices are too deeply implanted to be eradicated by any legislation. ${ }^{53}$

With this understanding the court offered its interpretation of the 1875 Act:

Any law which would impose upon the white race the imperative obligation of mingling with the colored race on terms of social equality would be repulsive to natural feeling and long established prejudices, and would be justly odious. There is no principle of law, human or divine, that requires all men to be thrown into social hotchpot in order that their equality of civil rights may be secured and enforced. The civil rights bill neither imposes nor was intended to impose any such social obligation. It only proposes to provide for the enforcement of legal rights guaranteed to all citizens by the laws of the land, and leaves social rights and privileges to be regulated, as they have ever been, by the customs and usages of society. ${ }^{54}$

In this interpretive framework, equality of access to public transportation was a civil right, but integrated access raised questions of social rights, and was unacceptable because it threatened status relations forged in the institution of slavery.

48. See id. at 1049-50 (citing Cong. Globe, 41st Cong., 2d Sess. 3434 (1870)).

49. See Avins, supra note 32, at 645-55; McConnell, supra note 28, at 1014-23.

50. 18 Stat. 335 (1875).

51. See Stephen J. Riegel, The Persistent Career of Jim Crow: Lower Federal Courts and the "Separate but Equal" Doctrine, 1865-1896, 28 Am. J. Legal Hist. 17, 21-27, 32 (1984). For an especially rich account of the evolution of legal doctrines sanctioning segregation in public accommodations, see Singer, supra note 28. See also id. at 1384-85 (discussing interpretation of the 1875 Act).

52. See Riegel, supra note 51, at 34 (quoting District Court Judge Amos Morrill of Texas); see also id. at 32-35 (discussing social rights discourse in interpretation of the 1875 Act). 18,258).

53. Charge to the Jury-The Civil Rights Act, 30 F. Cas. 999, 1001 (C.C.W.D.N.C. 1875) (No.

54. Id. 
The Supreme Court employed the language of social rights to interpret the Constitution, but, as it did so, it suppressed reference to many of the social understandings informing the discourse. For example, when the Court struck down the Civil Rights Act of 1875 in The Civil Rights Cases, ${ }^{55}$ it declared that Congress lacked power under the Thirteenth Amendment to enact the 1875 statute because-unlike the 1866 Civil Rights Act-the 1875 Act regulated "social rights" that had "nothing to do with slavery."56

Detached from its reference to slavery, social rights discourse played an even more prominent role in the Plessy decision, where it was invoked by the Court to explain why laws mandating racial segregation of public transportation were permissible under the Fourteenth Amendment:

The object of the amendment was undoubtedly to enforce the absolute equality of the two races before the law, but in the nature of things it could not have been intended to abolish distinctions based upon color, or to enforce social, as distinguished from political equality, or a commingling of the two races upon terms unsatisfactory to either. ${ }^{57}$

The Court pointed to its decision in Strauder $v$. West Virginia ${ }^{58}$ holding that states could not exclude blacks from jury service in order to emphasize "[t]he distinction between laws interfering with the political equality of the negro and those requiring the separation of the two races in schools, theaters and railway

55. 109 U.S. 3 (1883).

56. In holding that Congress lacked power to enact the 1875 Act under the Thirteenth Amendment, the Court distinguished the rights protected by the 1875 Act from those protected by the 1866 Civil Right Act:

[In 1866] Congress did not assume, under the authority given by the Thirteenth Amendment, to adjust what may be called the social rights of men and races in the community; but only to declare and vindicate those fundamental rights which appertain to the essence of citizenship, and the enjoyment or deprivation of which constitutes the essential distinction between freedom and slavery.

Id. at 22 (emphasis added). Continuing this line of analysis, the Court asked, "Can the act of a mere individual, the owner of the inn, the public conveyance or place of amusement, refusing the accommodation, be justly regarded as imposing any badge of slavery or servitude upon the applicant?" Id. at 24 . The Court then observed that:

such an act of refusal has nothing to do with slavery or involuntary servitude .... It would be running the slavery argument into the ground to make it apply to every act of discrimination which a person may see fit to make as to the guests he will entertain, or as to the people he will take into his coach or cab or car, or admit to his concert or theatre, or deal with in other matters of intercourse or business.

Id. at 24-25. Justice Harlan vigorously objected to the Court's characterization of the 1875 Act, conceding "that government has nothing to do with social, as distinguished from technically legal, rights of individuals," but contending that the "rights which Congress, by the act of 1875 , endeavored to secure and protect are legal, not social rights." Id. at 59 (Harlan, J. dissenting).

It is also possible to read the discourse of social rights as informing the principal holding in the case, that the 1875 Act exceeded Congress's powers under the Fourteenth Amendment. See id. at 11 (Fourteenth Amendment "does not authorize Congress to create a code of municipal law for the regulation of private rights; but to provide modes of redress against the operation of State laws, and the action of State officers."). The understandings reflected in the distinction between civil and social rights shaped doctrines of federalism and state action developed during the Reconstruction era, but exploration of such matters exceeds the scope of this essay. Cf. Siegel, supra note 4, at $2176 \mathrm{n} .222,2202-03$ (discussing nineteenth-century cases that invoke racial and gender concepts of the private to define the respective roles of federal and state government).

57. Plessy v. Ferguson, 163 U.S. 537, 544 (1896).

58. 100 U.S. 303 (1879). 
carriages."59 In Plessy, the Court again denied "that the enforced separation of the two races stamps the colored race with a badge of inferiority" 60 - even as the very language of its opinion discussed the "commingling of the two races" as an objectionable form of "social equality." To resolve this contradiction, the opinion attempted to characterize questions of equality as questions of liberty, and to describe status discriminations as expressions of taste and sensibility. Rejecting the plaintiff's argument that segregation connoted inferiority, the Court responded that:

[t]he argument ... assumes that social prejudices may be overcome by legislation, and that equal rights cannot be secured to the negro except by an enforced commingling of the two races. We cannot accept this proposition. If the two races are to meet upon terms of social equality, it must be the result of natural affinities, a mutual appreciation of each other's merits and a voluntary consent of individuals. . . . If the civil and political rights of both races be equal one cannot be inferior to the other civilly or politically. If one race be inferior to the other socially, the Constitution of the United States cannot put them upon the same plane. ${ }^{61}$

Thus, in Plessy, the Court contended that segregation did not connote inferiority, but conceded that if it did, it was inferiority of a sort that was beyond the power of law to rectify.

Justice Harlan's famous dissent in Plessy repeatedly chided the majority for denying what he called the "real meaning" of segregation: that "colored citizens are so inferior and degraded that they cannot be allowed to sit in public coaches occupied by white citizens." 62 But Justice Harlan did not assert that "colored citizens" were the social equals of white citizens, or that the law should make them so; indeed, passages of his dissent-including the famous color-blindness argument-continue to emphasize distinctions between legal and "social" equality. ${ }^{63}$ Justice Harlan broke with the majority because he, like

59. Plessy, 163 U.S. at 545.

60. Id. at 551.

61. Id. at 551-52 (emphasis added). In discussing matters of social equality in the language of sensibility, the Court was drawing on a rich tradition. See, e.g., CONG. GLOBE, 39th Cong., 1st Sess. 3434, 3437 (1866) (remarks of Sen. Waitman T. Willey) ("Social relations cannot be regulated by law. They are beyond its power. They are not the legitimate subject of legal regulation. Social equality is a matter of taste, of feeling, of every man's unfettered sense of propriety."), quoted in Avins, supra note 32 , at 643 .

62. Plessy, 163 U.S. at 560; see also id. at 557 (answering the argument that the segregation statute treats white and black citizens equally by invoking what "[e]very one knows" about the social meaning of racial separation, and concluding that "[n]o one would be so wanting in candor as to assert the contrary").

63. Justice Harlan wrote:

The white race deems itself to be the dominant race in this country. And so it is, in prestige, in achievements, in education, in wealth and in power. So, I doubt not, it will continue to be for all time, if it remains true to its great heritage and holds fast to the principles of constitutional liberty. But in view of the Constitution, in the eye of the law, there is in this country no superior, dominant, ruling class of citizens. There is no caste here. Our Constitution is color-blind, and neither knows nor tolerates classes among citizens. In respect of civil rights, all citizens are equal before the law.

Id. at 559; see also id. at 561 ("social equality no more exists between two races when traveling in a passenger coach or a public highway than when members of the same races sit by each other in a street car or in the jury box, or stand or sit with each other in a political assembly"); $c f$. The Civil Rights 
the Congress that enacted the 1875 Civil Rights Act, viewed equal access to public transportation as a civil right which, accordingly, could not be the subject of racially discriminatory regulation: "In respect of civil rights, all citizens are equal before the law."64 However, by the time Justice Harlan wrote his dissent in Plessy (two decades after passage of the 1875 Act), the discourse of social rights had largely displaced the language of civil rights in public accommodations law, facilitating the justification of segregation in terms that the architects of Reconstruction would have wholly repudiated. ${ }^{65}$

Although the concept of social rights was quite elastic, over time legitimating state sponsored segregation of an increasing variety of transactions, it was not infinitely elastic. In Buchanan v. Warley, ${ }^{66}$ the Court considered a challenge to a Kentucky city ordinance forbidding blacks to occupy houses in blocks where the greater number of houses were occupied by white persons. Defending the ordinance, the city invoked Plessy for the proposition that "[l]egislation segregating the white and colored races has universally been recognized by the courts as a constitutional exercise of the police power."67 But the Court distinguished Plessy and other precedents upholding segregation with the observation that:

[t]he case presented does not deal with an attempt to prohibit the amalgamation of the races. The right which the ordinance annulled was the civil right of a white man to dispose of his property if he saw fit to do so to a person of color and of a colored person to make such disposition to a white person. ${ }^{68}$

The Court struck down the ordinance on the grounds that it violated the Fourteenth Amendment and the civil rights statutes of 1866 and 1870. "These enactments did not deal with the social rights of men, but with those fundamental rights in property which [belong equally] to citizens of every race and color." 69 (It is consistent with the logic of Buchanan that several years later, the Court upheld the use of race-based restrictive covenants in real property transactions as a form of private discrimination not involving state action. ${ }^{70}$ )

Thus, considered in retrospect, the distinction between civil and political rights on the one hand, and social rights on the other, helps explain juridical differences in the rule structure of racial status regulation enacted in the decades following the Civil War. In matters deemed to concern civil and political rights, states over time came to regulate race relations by means of statutes that

Cases, 109 U.S. 3, 59 (1883) (Harlan, J., dissenting) ("I agree that government has nothing to do with social, as distinguished from technically legal rights of individuals. No govemment ever brought, or ever can bring, its people into social intercourse against their wishes.").

64. Plessy, 163 U.S. at 559.

65. Cf. McConnell, supra note 28, at 1120-26 ("Each of the arguments accepted by the Plessy majority had been urged in debate by the Act's opponents, but had been refuted by the proponents and ultimately rejected.").

66. 245 U.S. 60 (1917).

67. Id. at 65 .

68. Id. at 81 .

69. Id. at 79.

70. See Corrigan v. Buckley, 271 U.S. 323, 330-31 (1926). 
employed no express racial distinctions on their face. ${ }^{71}$ Thus, states seeking to disenfranchise African-Americans successively experimented with the grandfather clause, residency and literacy requirements, and "privatization" through the white primary, as well as the familiar tactics of racist intimidation and discriminatory administration of facially neutral registration statutes. ${ }^{72}$ It was in the sphere of so-called social rights (a sphere which ultimately was to include marriage, education, public transportation, and accommodation) that states openly employed race-based distinctions to enforce racial segregation.

The regime of segregation authorized by the social rights concept lasted well into the twentieth century, until the Court began its dismantlement in Brown. ${ }^{73}$ In this era, the discourse of social rights supplied a basis for opposing Brown. For example, Herbert Wechsler drew upon this tradition to advance his prominent critique of the Brown decision:

But if the freedom of association is denied by segregation, integration forces an association upon those for whom it is unpleasant or repugnant. ... Given a situation where the state must practically choose between denying the association to those individuals who wish it or imposing it on those who would avoid it, is there a basis in neutral principles for holding that the Constitution demands that the claims for association should prevail? 74 $^{4}$

In this period, similar arguments were advanced against civil rights legislation that would require businesses to deal with the public on a nondiscriminatory basis. ${ }^{75}$ So strong was the tradition of protecting white "associational" liberties

71. On voting, see, for example, ALA. CODE $\S 290$ (1907) (facially neutral voter qualification statute with residency and other requirements); id. $\S 312$ (facially neutral literacy requirements for voter registration); id. $\$ \S 512,513,521$ (facially neutral "white primary" laws); Miss. CODE ANN. ch. 68, $\$ \$ 8-12,31$ (1892) (facially neutral poll tax and voter registration laws that direct public officials to provide information about name, age, and race of voter); id. at ch. $69, \S \S 1,9$ (facially neutral "white primary" laws). On criminal law, see, for example, 1867 Miss. Laws ch. CLXX, § 4 (mandating same court proceedings for persons charged with crimes and repealing race-based disparities in punishment). On jury service, see Strauder v. West Virginia, 100 U.S. 303, 310 (1879) (holding that the Fourteenth Amendment prohibits laws that exclude African-Americans from serving on juries). On employment, see, for example, Bailey v. Alabama, 219 U.S. 219, 231, 245 (1911) (holding that a facially neutral statute making it a crime to refuse to perform a labor contract does not violate the Fourteenth Amendment, but enforces a form of compulsory peonage that violates the Thirteenth Amendment).

72. See, e.g., Smith v. Allwright, 321 U.S. 649, 660 (1944) (striking down white primary on grounds that "state delegation to a party of the power to fix the qualifications of primary elections is delegation of a state function that may make the party's action the action of the State"); Grovey v. Townsend, 295 U.S. 45, 52 (1935) (upholding Democratic Party's primary election restricted to white voters on the grounds that political parties in the state of Texas "are not the creatures of the state"); Guinn v. United States, 238 U.S. 347, 364-65 (1915) (striking down grandfather clause).

73. Brown v. Board of Educ., 347 U.S. 483 (1954).

74. Herbert Wechsler, Toward Neutral Principles of Constitutional Law, 73 HaRv. L. Rev. 1, 34 (1959). On the background and reception of the Wechsler article, see Gary Peller, Neutral Principles in the 1950's, 21 U. MiCH. J.L. REFORM 561 (1988).

75. See Robert Bork, Civil Rights-A Challenge, New Republic, Aug. 31, 1963, at 21 (objecting to a proposed interstate accommodations act on the grounds that it would compel "a substantial body of the citizenry" to "deal with and serve persons with whom they do not wish to associate"; characterizing race discrimination as "ugliness," but also characterizing the justification for legislation enforcing antidiscrimination norms in business transactions as "a principle of unsurpassed ugliness"); $c f$. Alfred Avins, Freedom of Choice in Personal Service Occupations: Thirteenth Amendment Limitations on Antidiscrimination Legislation, 49 CORNELI L.Q. 228 (1964) (arguing that state legislation requiring nondiscrimination in public accommodations and various personal service occupations violates the Thirteenth Amendment by forcing one person to serve another). 
that it was not until 1967, thirteen years after Brown was decided, that the Court was willing to declare that antimiscegenation statutes violated the equal protection clause. ${ }^{76}$ Only after the Court's decision in Loving ${ }^{77}$ struck down Virginia's antimiscegenation statute as an expression of "White Supremacy" could it be confidently asserted that the Court had adopted a categorical presumption against race-based regulation. ${ }^{78}$

\section{Status-Enforcing State Action Today: Why Equal Protection No LONGER PROTECTS}

Viewed retrospectively, the civil-political-social rights distinction may strike us as profoundly misguided, or worse. Yet for generations of white Americans this conceptual framework offered an entirely reasonable way of understanding the Fourteenth Amendment's guarantee of "equal protection of the laws." For these Americans, Plessy was not "wrong the day it was decided"; 79 to the contrary, the decision conformed with "common sense" intuitions about the meaning of equality in a constitutional democracy. The Fourteenth and Fifteenth Amendments guaranteed African-Americans equality in civil and political rights; equality in "social rights" was not to be enforced by law. Thus, constitutional scholars as eminent as Herbert Wechsler worried that the Court's decision in Brown lacked a basis in neutral principles because it protected the associational preferences of African-Americans at the expense of whites who might find association with African-Americans "unpleasant or repugnant." 80 In raising such objections, Wechsler and others who defended the constitutional liberties of white Americans to choose their associations were speaking in "good faith," invoking principles that had governed the meaning of equal protection for generations.

The civil-political-social rights distinction thus offered a framework within which white Americans could disestablish slavery, guarantee the emancipated slaves equality at law, and yet continue to justify policies and practices that perpetuated the racial stratification of American society. Once we appreciate how conflicts over the disestablishment of slavery produced the constitutional framework authorizing segregation, we are in a better position to think about the ways in which the Court interprets the Equal Protection Clause today.

Just as the interpretation of equal protection offered in Plessy emerged from the Court's efforts to disestablish slavery, the interpretation of equal protection we inherit today emerged from the Court's efforts to disestablish segregation.

76. The Court avoided consideration of miscegenation statutes in two cases during the mid-1950s, Jackson v. State, 72 So. 2d 114 (Ala.), cert. denied, 348 U.S. 888 (1954) and Naim v. Naim, 350 U.S. 891 (1955) (per curiam) (declining to review the Virginia miscegenation statute). See Michael Klarman, An Interpretive History of Modern Equal Protection, 90 MicH. L. Rev. 213, 242-43 (1991) (discussing the Supreme Court's reluctance to review problems of miscegenation posed by Jackson and Naim for fear of "stir[ring] up another hornets' nest in the immediate wake of Brown").

77. Loving v. Virginia, 388 U.S. 1 (1967).

78. See id. at $11 ;$ cf. Klarman, supra note 76 , at $226-45$ (arguing that the Court did not clearly adopt a "racial classification rule" until Loving).

79. See text accompanying note 1 supra.

80. See text accompanying note 74 supra. 
Has the body of equal protection law that disestablished segregation prohibited all forms of state action that perpetuate the racial stratification of American society? Quite plainly, it has not. Equal protection doctrine currently constrains explicitly race-based forms of state action; but, as the Court has repeatedly held, the state may enforce "facially neutral" policies and practices with a disparate impact on minorities or women so long as such policies or practices are not enacted for discriminatory purposes. ${ }^{81}$

In the nineteenth century, the Court was confident that it had abolished slavery and granted African-Americans equal protection of the laws. In this period, doctrines concerning social rights authorized certain forms of state action that perpetuated racial stratification as consistent with constitutional guarantees of equal protection. Today, the Court is confident that it has abolished segregation and granted African-Americans equal protection of the laws. Now, doctrines concerning discriminatory purpose authorize certain forms of state action that perpetuate racial stratification as consistent with constitutional guarantees of equal protection. If we assume that status-enforcing state action has no transhistorical form, but instead evolves in rule structure and rhetoric as it is contested, we might conclude that the reigning interpretation of equal protection has once again caused a shift in the forms of state action that perpetuate the racial stratification of American society.

From this perspective we might reason that, just as the conflicts culminating in the disestablishment of slavery produced a shift in the rule structure and justificatory rhetoric of racial status law, the conflicts culminating in the disestablishment of segregation have produced yet another shift in the rule structure and justificatory rhetoric of racial status law. Now status-enforcing state action is facially neutral in form (as it was in the nineteenth century, in matters deemed to concern "civil" or "political" rights), and it is justified as serving ends that do not amount to "discriminatory purposes," as the Court has constitutionally defined the term. This is one view of the matter we might adopt, if we assume that status-enforcing state action is mutable in form.

Resisting such a view, we might insist, as the Court does, that the Constitution permits the state to act in ways that perpetuate, or even aggravate, the racial stratification of American society; it is only race-based state action or state action animated by racially discriminatory purposes that violates tenets of equal protection, nothing more. In this view, we stand at the end of history, finally and conclusively repudiating the legacy of Dred Scott ${ }^{82}$ and Plessy. Even for those readers who embrace the prevailing interpretation of equal protection as the "true" and "right" meaning of equal protection, the history recounted in Part I of this essay should counsel a certain degree of caution, illustrating, as it does, that core convictions about the meaning of equal protection can and do evolve over time. I therefore invite such readers to assume an imaginary standpoint in the middle of the twenty-first century, and take a retrospective view of the evolution of our current constitutional framework.

81. See text accompanying notes $98-117$ infra.

82. Dred Scott v. Sandford, 60 U.S. (19 How.) 393 (1857). 
In this Part of the essay, I briefly rehearse the emergence of modern doctrines of equal protection with a view to illustrating how the Court's current interpretation of the Fourteenth Amendment continues to authorize forms of state action that contribute to the racial and gender stratification of American society. This analysis will show that, with the demise of the social rights concept and the forms of apartheid it authorized, debate over the meaning of equal protection came to focus on facially neutral state action having a disparate impact on constitutionally protected classes. At this juncture, doctrines of discriminatory purpose began to play an important role in determining the kinds of state action prohibited by the Equal Protection Clause. ${ }^{83}$

In the brief account of discriminatory purpose doctrine that follows, I analyze its emergence and elaboration with a view to raising the following question: Might doctrines of discriminatory purpose be performing much the same work for late twentieth century America that the civil-political-social rights distinction performed for late nineteenth-century America?

\section{A. The Emergence of Discriminatory Purpose Doctrine}

The Court's decision to apply strict scrutiny to race-based state action in the 1950s and 1960s was momentous, given the wide variety of circumstances in which the Court had previously sanctioned explicit discrimination under the Equal Protection Clause. Once Brown and Loving demonstrated that the Court had definitively repudiated the old distinction between civil and social rights, there was no longer a tenable basis for defending the constitutionality of overtly race-based regulation. State regulation of matters once held to concern social rights thus assumed the facially neutral form that had generally characterized regulation of matters deemed to concern civil and political rights since the Reconstruction era.

Collapse of the distinction between civil and social rights shifted the terrain of conflict. In the years after Brown, controversy in the school segregation cases evolved from questions concerning the constitutionality of openly racebased admissions policies to questions concerning the constitutionality of admissions policies employing facially neutral criteria that, plaintiffs claimed, operated in a biased manner or were applied in a discriminatory fashion. ${ }^{84}$ As plaintiffs began to bring equal protection challenges against school districts in northern jurisdictions that had never statutorily mandated segregated admissions, courts began to distinguish between de jure and de facto segregation. In this framework, racial disparities in school populations violated the Equal Protection Clause only if plaintiffs could prove that state actors intended to segre-

83. Of course, to analyze ways in which conflicts over the permissible forms of racial regulation have shaped the contours of modern equal protection doctrine, we might also examine doctrines defining "state action" itself, or many other subfields of equal protection law. I analyze the emergence of discriminatory purpose doctrine in order to illustrate the dynamic in one very significant area of equal protection jurisprudence.

84. See, e.g., Green v. County Sch. Bd., 391 U.S. 430 (1968) (addressing constitutionality of "freedom of choice" school attendance plans). 
gate the schools. ${ }^{85}$ The development elicited a sharp, regionally based protest from Justice Powell:

Unwilling and footdragging as the process was in most places, substantial progress toward achieving integration has been made in Southern States. No comparable progress has been made in many nonsouthern cities with large minority populations primarily because of the de facto/de jure distinction nurtured by the courts and accepted complacently by many of the same voices which denounced the evils of segregated schools in the South. But if our national concern is for those who attend such schools, rather than for perpetuating a legalism rooted in history rather than present reality, we must recognize that the evil of operating separate schools is no less in Denver than in Atlanta. ${ }^{86}$

Despite objections that the de facto/de jure distinction was a "legalism," the Court embraced the concept of discriminatory purpose as the touchstone for determining the constitutionality of facially neutral state action alleged to discriminate on the basis of race.

It was in no sense natural, inevitable, or necessary for the Court to interpret the Equal Protection Clause this way. In the years after Brown, prominent legal process scholars such as Alexander Bickel and Herbert Wechsler suggested that it was inappropriate for judges to inquire into the motives of legislators in determining whether statutes comported with constitutional requirements. ${ }^{87}$ And the Court itself asserted as much in several of its opinions in the late 1960s and early 1970s. Although in 1960 the Court in Gomillion v. Lightfoot ${ }^{88}$ stated that "[a]cts generally lawful may become unlawful when done to accomplish an unlawful end," 89 by 1968 , the Court cast aspersion on the propriety of reviewing legislative motivation in a First Amendment opinion that announced: "The decisions of this court from the beginning lend no support whatever to the assumption that the judiciary may restrain the exercise of lawful power on the assumption that a wrongful purpose or motive has caused the power to be exerted."90 The Court again emphasized this view in Palmer $v$. Thompson, ${ }^{91}$ a race discrimination case decided in 1971, which held that a city's decision to close segregated public swimming pools rather than integrate them could not be impugned on the basis of legislative motivation alone. ${ }^{92}$ In Palmer, the Court announced that "no case in this Court has held that a legislative act may violate equal protection solely because of the motivations of the men who voted for it,"93 and proceeded to rehearse again the reasons why it deemed this form of

85. See Keyes v. School Dist. No. 1, 413 U.S. 189, $205-13$ (1973).

86. Id. at 218-19 (Powell, J., concurring in part, dissenting in part).

87. See Alexander Bickel, The Least Dangerous Branch 208-21 (1962); Wechsler, supra note 74, at 33 (observing that the Court's decision in Brown likely "involve[d] an inquiry into the motives of the legislature, which is generally foreclosed to the courts").

88. 364 U.S. 339 (1960).

89. Id. at 347 (quoting Western Tel. Co. v. Foster, 247 U.S. 105, 114 (1918) (citation omitted).

90. United States v. O'Brien, 391 U.S. 367, 383 (1968) (quoting McCray v. United States, 195 U.S. 27, 56 (1904)).

91. 403 U.S. 217 (1971).

92. See id. at 224-26.

93. Id. at 224. 
review inappropriate. That same year, in Griggs v. Duke Power Co., ${ }^{94}$ the Court held that, under Title VII of the Civil Rights Act of 1964, plaintiffs could prove claims of employment discrimination on a showing of disparate impact evidence alone. 95

A period of uncertainty about constitutional standards ensued. In this period, second-generation legal process scholars, who were critical of the Court's decision in Palmer, began to defend motive review as important in determining the forms of legislative action to which courts should properly defer, ${ }^{96}$ while other constitutional commentators began openly to worry about the practical consequences of allowing plaintiffs to challenge facially neutral laws with racially disparate impacts. ${ }^{97}$ A number of federal courts were deciding equal protection challenges to facially neutral state action on the basis of evidence of racial impact alone, and the Court moved sharply to curb this practice. Reversing one such case in 1976, the Court in Washington v. Davis ${ }^{98}$ announced that there was an important distinction between equal protection and Title VII standards, and drew upon the school segregation cases to assert the general principle that plaintiffs challenging facially neutral state action would have to demonstrate that the state acted with discriminatory purpose in order to make out an equal protection violation. ${ }^{99}$ Davis repudiated the Court's prior statements that impugned motive analysis as "dicta," and expressly criticized the many appellate court opinions that had found equal protection violations on the basis of impact evidence alone. ${ }^{100}$ Thus, in Davis, a case involving a challenge to an employment exam that excluded four times as many African-Americans

94. 401 U.S. 424 (1971).

95. See id. at 432.

96. See Paul Brest, Palmer v. Thompson: An Approach to the Problem of Unconstitutional Legislative Motive, 1971 SuP. Cr. REv. 95, 115-18 [hereinafter Brest, Legislative Motive] (observing that "[i]n our governmental system ... only the political decisionmaker-and not the judiciary-has general authority to assess the utility and faimess of a decision") (footnote omitted); see also John Hart Ely, Legislative and Administrative Motivation in Constitutional Law, 79 Y ALE L.J. 1205 (1970). For later elaborations of this work, see JoHn Hart Ely, DEMOCRACY and Distrust: A THEORY OF JUdicial. REVIEw 136-45 (1980) (arguing that the motivation of government acts is often appropriately considered in constitutional analysis); Paul Brest, Foreword: In Defense of the Antidiscrimination Principle, 90 HARV. L. REv. 1, 12-14 (1976) [hereinafter Brest, Antidiscrimination Principle] (developing motivation analysis through an account of an antidiscrimination principle that forbids race-dependent decisionmaking).

97. See Washington v. Davis, 426 U.S. 229, 248 n.14 (1976) (discussing three such articles); see also Brest, Antidiscrimination Principle, supra note 96, at 11; Brest, Legislative Motive, supra note 96, at 110. But cf. Owen M. Fiss, Groups and the Equal Protection Clause, 5 PHI. \& Pus. AFr. 107, 14146, 157-58, 165-68 (1976) (arguing that the Equal Protection Clause prohibits state laws and practices that aggravate or perpetuate the subordinate position of a specially disadvantaged group).

98. 426 U.S. 229 (1976).

99. See id. at 246-48 (announcing a distinction between Title VII and equal protection standards).

Drawing upon the school cases, the Court explained:

The school desegregation cases have also adhered to the basic equal protection principle that the invidious quality of a law claimed to be racially discriminatory must ultimately be traced to a racially discriminatory purpose. That there are both predominantly black and predominantly white schools in a community is not alone violative of the Equal Protection Clause. The essential element of de jure segregation is "a current condition of segregation resulting from intentional state action."

Id. at 240 (quoting Keyes v. School Dist. No. 1, 413 U.S. 189, 205 (1973)).

100. See id. at $244,245 \&$ n. 12 . 
as whites applying for a position on the District of Columbia police force, ${ }^{101}$ and a year later in Village of Arlington Heights v. Metropolitan Housing Development Corp., ${ }^{102}$ a case involving a challenge to a zoning ordinance prohibiting the construction of low and moderate income housing, the Court made clear that proving discriminatory purpose was now not only permitted, but required in all cases challenging facially neutral state action having a disparate impact on protected classes.

Yet, even as the Court announced its new-found commitment to motive review, it continued to emphasize that plaintiffs might draw upon evidence of racial impact to prove a claim of discriminatory purpose. ${ }^{103}$ It was not until its 1979 decision in Personnel Administrator v. Feeney, ${ }^{104}$ a sex discrimination case in which the Court defined discriminatory purpose under the Equal Protection Clause, that the Court made clear that it had raised quite a formidable barrier to plaintiffs challenging facially neutral state action.

The Feeney case involved a challenge to a veteran's preference statute that functioned to exclude most women from the upper levels of civil service employment in the State of Massachusetts. ${ }^{105}$ The plaintiff argued that the Massachusetts legislature could easily have foreseen that the statute it adopted would have just this effect, given that federal law barred most women from military service during this period. ${ }^{106}$ But the Court held that the foreseeable impact of a statute was by itself not sufficient to make out a case of discriminatory purpose under the Equal Protection Clause. ${ }^{107}$ The Court reasoned that: "'[d]iscriminatory purpose' . . . implies more than intent as volition or intent as awareness of consequences. It implies that the decisionmaker . . . selected or reaffirmed a particular course of action at least in part 'because of,' not merely 'in spite of' its adverse effects upon an identifiable group."108 In so holding, the Court rejected the possibility that plaintiffs might prove that legislators had acted with unconscious bias of the sort Paul Brest had termed "selective sympathy and indifference" in an influential article advocating motive review. ${ }^{109}$ And in rejecting forms of conscious intent it termed "volition" or "awareness of consequences," the Court deemed tort standards of foreseeability an inadequate basis for holding state actors accountable for their actions under the Equal Pro-

101. See id. at 237 .

102. 429 U.S. 252 (1977).

103. See Arlington Heights, 429 U.S. at 265-66; Davis, 426 U.S. at 242. Casteneda v. Partida, 430 U.S. 482 (1977), a grand jury exclusion case decided in this period, applied the purpose requirement in an especially lenient way. Drawing on a long line of precedent in the area, the Court ruled that a plaintiff could make out a prima facie case of discriminatory purpose by showing that minorities were substantially underrepresented in the grand jury and that the procedures employed to select the jury were susceptible to abuse; with such a showing, the burden would shift to the government to rebut the inference of discrimination. See id. at 492-95.

104. 442 U.S. 256 (1979).

105. See id. at 259 .

106. See id. at 278 .

107. See id. at $279-80$.

108. Id. at 279 (citations omitted).

109. See Brest, Antidiscrimination Principle, supra note 96, at 7-8. 
tection Clause. ${ }^{110}$ Instead, in Feeney, the Court asked plaintiffs to prove that legislators adopting a policy that would foreseeably injure women or minorities had acted with the express purpose of injuring women or minorities-in short, a legislative state of mind akin to malice.

In Rogers $v$. Lodge, ${ }^{111}$ a 1982 case involving an equal protection challenge to an at-large electoral system, the Court addressed the plaintiffs' burden in proving discriminatory purpose without ever adverting to its decision in Feeney. ${ }^{112}$ But in 1987, when the Court rejected an equal protection challenge to the death penalty (based on a statistical study demonstrating racial bias in capital sentencing decisions), its decision in McCleskey v. Kemp ${ }^{113}$ relied in significant part on Feeney's definition of discriminatory purpose:114 "For this claim to prevail, McCleskey would have to prove that the Georgia Legislature enacted or maintained the death penalty statute because of an anticipated racially discriminatory effect." 115 Observing that McCleskey's claim threatened discretionary decisionmaking central to the criminal justice system, the Court concluded by observing that, because of these systemic implications, "McCleskey's arguments are best presented to the legislative bodies."116 It was this conclusion that the Court's application of the Feeney purpose requirement was intended to effectuate. 117

\section{B. The Purpose Requirement in Historical Context: Some Questions}

In Feeney, the Court defined discriminatory purpose in terms that are extraordinarily difficult to prove in the constitutional culture its modern equal protection opinions have created-a culture that now embraces "equal opportunity" and "nondiscrimination" as a form of civic religion. ${ }^{118}$ Because doctrines of heightened scrutiny now require legislators enacting race- or sex-based programs to articulate legitimate, nondiscriminatory reasons for their policy choices, ${ }^{119}$ legislators do not make a practice of justifying legislation on the grounds that it will adversely affect groups that have historically been subject to discrimination. To the contrary, doctrines of heightened scrutiny have cre-

110. Cf. Feeney, 442 U.S. at 279 n. 25 (suggesting that "the inevitability or foreseeability of consequences of a neutral rule" might, but need not, have bearing upon the existence of a discriminatory intent).

111. 458 U.S. 613 (1982).

112. Id. at $623-28$.

113. 481 U.S. 279 (1987).

114. Id. at 298.

115. Id.

116. Id. at 319.

117. Cf. id. at 312-13 ("At most, the Baldus study indicates a discrepancy that appears to correlate with race. Apparent disparities in sentencing are an inevitable part of our criminal justice system. ... Where the discretion that is fundamental to our criminal process is involved, we decline to assume that what is unexplained is invidious.").

118. For sociological surveys documenting the changing attitudes of Americans toward matters of equality in the post-World War II period, see note 3 supra.

119. See, e.g., Craig v. Boren, 429 U.S. 190, 204 (1976) (requiring heightened scrutiny of sexbased state action); Loving v. Virginia, 388 U.S. 1, 11-12 (1967) (requiring strict scrutiny of race-based state action). 
ated incentives for legislators to explain their policy choices in terms that cannot be so impugned.

The Court has thus adopted a working definition of discriminatory purpose that raises a substantial barrier to suits challenging facially neutral state action. The Court itself has acknowledged as much, observing that "[p]roving the motivation behind official action is often a problematic undertaking," 120 and more bluntly still, "[ $t]$ he distinction between being aware of racial considerations and being motivated by them may be difficult to make." 121 Because it is so hard to prove discriminatory purpose under the Equal Protection Clause, most institutions, practices, and values will be constitutionally characterized as race- or sex-neutral. Thus, in Feeney, the Court characterized a veterans' preference statute that gave most covered civil service jobs to men as sex-neutral "in the constitutional sense,"122 and more recently characterized the practice of drawing voting district lines to reflect "compactness, contiguity, respect for political subdivisions or communities defined by actual shared interests" as an expression of "traditional race-neutral districting principles." 123

For these reasons, the discriminatory purpose requirement now insulates many, if not most, forms of facially neutral state action from equal protection challenge. (Indeed, a recent study hypothesizes that "[t]he intent standard's demands might discourage plaintiffs from bringing intent-based claims," offering statistics suggesting that on average, just one or two intent claims are filed per federal district per year. ${ }^{124}$ ) What concerns justify the Feeney framework?

In defining discriminatory purpose, the Court did not consult sociological or psychological studies of racial bias. Had it done so, it would have encountered surveys and polls documenting that the majority of white Americans repudiate "dominative" racism of the sort contemplated by Feeney's definition of discriminatory purpose. ${ }^{125}$ At the same time, the empirical literature on racial bias demonstrates that there is a significant difference between the principles that white Americans espouse in such polls and their actual attitudes in matters of race. These studies demonstrate that many white Americans now view overt racism as socially unacceptable and mute expression of their racially biased opinions in public settings - even settings as relatively anonymous as an opinion poll or survey. ${ }^{126}$ And an even larger body of literature demonstrates that white Americans who embrace principles of racial equality manifest unconscious forms of racial bias in diverse spheres of social life. ${ }^{127}$ In sum, the

120. Hunter v. Underwood, 471 U.S. 222, 228 (1985).

121. Miller v. Johnson, 115 S. Ct. 2475, 2488 (1995) (remarking on Feeney's specific intent requirement).

122. Personnel Adm'r v. Feeney, 442 U.S. 256, 277 n.23 (1979).

123. Miller, $115 \mathrm{~S}$. Ct. at 2488.

124. Theodore Eisenberg \& Sheri Lynn Johnson, The Effects of Intent: Do We Know How Legal Standards Work?, 76 CoRNell L. Rev. 1151, 1166-67 (1991).

125. See note 3 supra.

126. See, e.g., Oppenheimer, supra note 3, at 904-911.

127. See, e.g., Faye Crosby, Stephanie Bromley \& Leonard Saxe, Recent Unobtrusive Studies of Black and White Discrimination and Prejudice: A Literature Review, 87 Psych. Bull. 546 (1980); Samuel L. Gaertner \& John F. Dovidio, The Aversive Form of Racism, in Prejudice, Discrimination, AND RACISM 61 (John F. Dovidio \& Samuel L. Gaertner eds., 1986). For a legal analysis of some of this 
sociological and psychological literature demonstrates that (1) racial bias remains the norm among white Americans; but that (2) they are strongly inhibited in expressing the racial attitudes they consciously hold, and often are wholly unaware of the extent to which their conscious judgments are unconsciously race based. Thus, the form of discriminatory purpose the Court asked plaintiffs to prove in Feeney ("that the decisionmaker ... selected or reaffirmed a particular course of action at least in part 'because of,' not merely 'in spite of,' its adverse effects upon an identifiable group"128) is one that the sociological and psychological studies of racial bias suggest plaintiffs will rarely be able to prove. In short, the empirical literature on racial bias suggests that, under the Feeney framework, most race-dependent governmental decisionmaking will elude equal protection scrutiny. ${ }^{129}$

The equal protection cases discussing discriminatory purpose never advert to this large body of empirical literature on the sociology and psychology of bias, because, it would appear, discriminatory purpose doctrine is responsive to a fundamentally different set of concerns. The Court's decisions in Davis, Fee$n e y$, and $\mathrm{McCl}$ eskey reason about the requirement of discriminatory purpose in terms focused on the relations of courts and the coordinate branches of government whose work is subject to judicial review. ${ }^{130}$ Several commentators argue that the discriminatory purpose requirement finds its deep roots in the legal

literature, see Barbara J. Flagg, "Was Blind, But Now I See": White Race Consciousness and the Requirement of Discriminatory Intent, 91 Mich. L. Rev. 953, 983-85 (1993); Oppenheimer, supra note 3, at 911-14. See generally Charles R. Lawrence III, The Id, the Ego, and Equal Protection: Reckoning With Unconscious Racism, 39 STAN. L. REV. 317 (1987) (arguing that government practices motivated by unconscious racial bias should violate equal protection).

128. Personnel Adm'r v. Feeney, 442 U.S. 256, 279 (1979).

129. For similar reasons, many forms of gender bias will elude detection under the Feeney framework, as well. As the vast literature on gender stereotyping suggests, unconscious stereotypes about women play an important role in causing discrimination. See, e.g., Madeline E. Heilman, Sex Bias in Work Settings: The Lack of Fit Model, 5 REs. ORG. Behav. 269, 270-86 (1983) (analyzing studies that link sex stereotyping and workplace discrimination); Linda Hamilton Krieger, The Content of Our Categories: A Cognitive Bias Approach to Discrimination and Equal Employment Opportunity, 47 STAN. L. REv. 1161 (1995) (criticizing antidiscrimination law for failing to recognize unintentional forms of categorization and intergroup bias); Price Waterhouse v. Ann B. Hopkins, Amicus Brief for the American Psychological Association, 46 AM. Psychol. 1061, 1062 (1991) ("research indicates that stereotyping is part of the normal process of categorization that under pertinent conditions can lead to inaccurate generalizations about individuals often transformed into discriminatory behavior").

130. See Washington v. Davis, 426 U.S. $229,247-48$ (1976) (Title VII disparate impact analysis "involves more probing judicial review of, and less deference to, the seemingly reasonable acts of administrators and executives than is appropriate under the Constitution where special racial impact, without discriminatory purpose, is claimed."); Feeney, 442 U.S. at 272 ("The calculus of effects, the manner in which a particular law reverberates in society, is a legislative and not a judicial responsibility."); McCleskey v. Kemp, 481 U.S. 279, 319 (1987) ("McCleskey's arguments are best presented to the legislative bodies. It is not the responsibility-or indeed even the right-of this Court to determine the appropriate punishment for particular crimes."); see also Brest, Legislative Motive, supra note 96, at 116-17 ("In our governmental system ... only the political decisionmaker-and not the judiciary-has general authority to assess the utility and fairness of a decision.") (footnote omitted), cited in Village of Arlington Heights v. Metropolitan Hous. Dev. Corp., 429 U.S. 252, 266 n.12 (1977). Justice Rehnquist discussed in some detail the institutional concerns embodied in the discriminatory purpose requirement in Columbus Bd. of Educ. v. Penick, 443 U.S. 449 (1979), a case decided just after Feeney. See id. at 510 (Rehnquist, J., dissenting) (requiring proof of discrimination as defined in Feeney "is important: both to limit federal courts to their constitutional missions and to afford school boards the latitude to make good faith, colorblind decisions ... without extensive [judicial] inquiries"). 
process tradition. ${ }^{131}$ But one need not follow this line of argument to appreciate that discriminatory purpose, as discussed in the Court's equal protection cases, is a juridicial concept that does not refiect prevailing understandings of the ways in which racial or gender bias operates, but instead functions to protect the prerogatives of coordinate branches of government whose work is subject to equal protection review. When the Supreme Court first announced the requirement that plaintiffs challenging facially neutral state action would have to prove discriminatory purpose, it refused to adopt an alternate "disparate impact" standard, drawn from its employment discrimination cases, that would have dispensed with such a showing on the grounds that the Title VII inquiry "involves a more probing judicial review of, and less deference to, the seemingly reasonable acts of administrators and executives than is appropriate under the Constitution where special racial impact, without discriminatory purpose, is claimed."132 Indeed, in Davis, the Court openly worried that relinquishing the purpose requirement would leave too many forms of regulation vulnerable to equal protection challenge. ${ }^{133}$ It then supplied a definition of discriminatory purpose in Feeney that plaintiffs could rarely muster the evidence to prove. ${ }^{134}$

Thus, Supreme Court cases invite judges to apply the discriminatory purpose requirement with an eye to issues concerning the deference that courts owe coordinate branches of government. With such concerns in mind, judges can adhere to the requirement of discriminatory purpose announced in Davis, and, when they deem the circumstances appropriate, allow plaintiffs to prevail on a lesser showing of purpose than Feeney contemplates. The Court itself illustrated this technique in its disposition of an equal protection challenge to an at-large electoral scheme in Rogers $v$. Lodge, ${ }^{135}$ the voting rights case it decided midway between Feeney and McCleskey, which never adverted to Feeney's onerous definition of discriminatory purpose. Indeed, Daniel Ortiz argues that "[i]nstead of regulating the inputs to decisionmaking, intent serves ... as a way of judging substantive outcomes," with Supreme Court cases "allocating burdens of proof between the individual and the state ... differently in different contexts."136 In matters involving "voting, jury selection, and sometimes education," Ortiz concludes, Supreme Court cases allocate evidentiary burdens in ways that "make judicial intervention more likely."137 The

131. See Barbara J. Flagg, Enduring Principle: On Race, Process, and Constitutional Law, 82 CAL. L. Rev. 935, 954-59 (1994); Daniel Ortiz, The Myth of Intent in Equal Protection, 41 Stan. L. REv. 1105, 1105-06 (1989); Sheila Foster, Intent and Incoherence (unpublished manuscript, on file with the author).

132. See Davis, 426 U.S. at 247 (emphasis added).

133. See id. at $248 \&$ n.14 ("A rule that a statute designed to serve neutral ends is nevertheless invalid, absent compelling justification, if in practice it benefits or burdens one race more that another would be far reaching and would raise serious questions about, and perhaps invalidate, a whole range of tax, welfare, public service, regulatory, and licensing statutes that may be more burdensome to the poor and to the average black than to the more affiuent white.").

134. See text accompanying notes 118-129 supra.

135. 458 U.S. 613 (1982).

136. Ortiz, supra note 131 , at 1107.

137. Id. For an even more elaborate legal process analysis of the Court's application of the discriminatory purpose requirement, see Foster, supra note 131. 
Supreme Court has never explicitly endorsed such a "fundamental rights" approach to applying the discriminatory purpose requirement; yet, to the extent that its decisions can be so described, ${ }^{138}$ the doctrine of discriminatory purpose perpetuates, in a new juridicial framework, distinctions between "political" and "social" rights of the sort that once undergirded the Court's decision in Plessy. ${ }^{139}$ A much larger study is required to determine whether lower courts are applying the purpose requirement in ways that respect such distinctions. But even if no coherent pattern governs application of the purpose requirement in the lower courts today, Ortiz is surely right that the body of Supreme Court discriminatory purpose cases decided before and after Feeney leaves judges with substantial discretion in determining which forms of facially neutral state action should survive equal protection challenge.

In short, courts now use Feeney's definition of discriminatory purpose to justify a decision to uphold facially neutral state action that has a disparate impact on protected classes. For example, in United States v. Clary ${ }^{140}$ the Eighth Circuit considered an equal protection challenge to federal sentencing guidelines that punish the possession and distribution of fifty grams of crack cocaine with the same ten-year sentence that is applied to the possession and distribution of five thousand grams of powder cocaine-a ratio of 100 to one. ${ }^{141}$ The sentencing guidelines' discrepant treatment of crack and powder cocaine had a predictably disproportionate racial impact. As the appellate court reported, the district court found that:

98.2 percent of defendants convicted of crack cocaine charges in the Eastern District of Missouri between the years 1988 and 1992 were African American. Nationally, 92.6 percent of those convicted of crack cocaine charges were African American, as opposed to 4.7 percent who were white. With respect to powder cocaine, the percentages were largely reversed..$^{142}$

The Eighth Circuit nevertheless upheld the sentencing guidelines in an opinion that explicitly invoked Feeney's definition of discriminatory purpose five times

138. A number of opinions Oriz analyzes antedate Feeney (for example, the jury case, Castaneda v. Partida, 430 U.S. 482 (1977) and the school desegregation case, Keyes v. School Dist. No. 1, 413 U.S. 189 (1973)), and so hardly can be said to deviate from its more exacting requirements. For his analysis of these cases, see Ortiz, supra note 131, at 1120, 1131.

139. Plessy v. Ferguson, 163 U.S. 545 (1879). Discriminatory purpose doctrine may tacitly embody a hierarchy of rights with roots in the nineteenth century, but our understanding of "fundamental" rights has itself evolved in the intervening period. In the nineteenth century, Americans viewed civil rights as fundamental and political rights as a privilege that some, but not all, citizens possessed; constitutional reform in the Reconstruction era played an important role in eroding this distinction. Our current understanding of "political" rights is shaped by twentieth-century legal-process traditions that deem political rather than civil rights fundamental. I am indebted to Jack Balkin for raising questions about the ways in which contemporary understandings diverge from the civil-political-social rights framework of the nineteenth century.

140. 34 F.3d 709 (8th Cir. 1994).

141. See id. at 710; see also U.S. Sentencing GuIdelines Manual § 2D1.1(C)(12)-(13) (1995); 21 U.S.C. § 841 (a)-(b) (1994).

142. Clary, 34 F.3d at 711 (citations omitted). For other, somewhat different, figures on the racial distribution of convictions that occurred nationwide during the 1993 calendar year, see U.S. SENTENCING Comm's, Special Report to the Congress: Cocaine and Federal Sentencing Policy 156, 161 , $162-63$ (1995). 
in the space of two pages. ${ }^{143}$ Its analysis was predictable. The Eighth Circuit panel argued that Congress did not adopt the sentencing differential "because of' its impact on African-Americans; rather, Congress had reasons for determining that crack cocaine posed a greater societal threat than powder cocaine, and this judgment in turn supplied justification for adopting the 100 to one sentencing ratio despite its foreseeable adverse impact on African-Americans. ${ }^{144}$ The Eighth Circuit's opinion in Clary is especially striking because it overturned a lengthy lower court decision that explored the history of racial bias in the criminal justice system and the sociology of the recent war on drugs, striking down the sentencing guidelines on the grounds that they manifested unconscious racial bias. ${ }^{145}$ To my knowledge the district court opinion reversed in Clary is the only federal opinion striking down the crack provisions of the sentencing guidelines. And like the Eighth Circuit decision in Clary, most federal circuits uphold the guidelines in opinions that explicitly rely on Feeney's definition of discriminatory purpose. ${ }^{146}$

My point here is not to debate the equities of the sentencing guidelines, ${ }^{147}$ but to raise a more general question about the way in which the doctrine of discriminatory purpose currently operates in the American legal system. Is Feeney's definition of discriminatory purpose a sufficient framework in which to evaluate whether Congress, in adopting or declining to amend ${ }^{148}$ the sentencing guidelines, provided African-Americans equal protection of the laws? Feeney stands as a gateway to challenges concerning residential zoning, education, and the operation of the criminal justice system. ${ }^{149}$ Likewise, all circuits to consider the question have held that Feeney supplies the framework for determining whether "spousal" violence policies provide women equal protection

143. See Clary, 34 F.3d at 712-13.

144. See id. at 712-14.

145. See United States v. Clary, 846 F. Supp. 768, 774-82 (E.D. Mo.), rev'd, 34 F.3d 709 (8th Cir. 1994); see also Jason A. Gillmer, Note, United States v. Clary: Equal Protection and the Crack Statute, 45 AM. U. L. REv. 497 (1995) (analyzing in detail the arguments supporting the district court opinion).

146. See United States v. Teague, 93 F.3d 81, 85 (2d Cir. 1996), cert. denied, 117 S. Ct. 708 (1997); United States v. Carter, 91 F.3d 1196, 1198 (8th Cir. 1996); United States v. Dumas, 64 F.3d 1427, 1429 (9th Cir. 1995), cert. denied, 116 S. Ct. 1341 (1996); United States v. Johnson, 40 F.3d 436, 439 (D.C. Cir. 1994), cert. denied, 115 S. Ct. 1412 (1995); United States v. Byse, 28 F.3d 1165, 1169 (11th Cir. 1994), cert. denied, 115 S. Ct. 767 (1995); United States v. Thurmond, 7 F.3d 947, 952 (10th Cir. 1993); United States v. Chandler, 996 F.2d 917, 918 (7th Cir. 1993); United States v. Galloway, 951 F.2d 64, 65 (5th Cir. 1992); see also United States v. Singleterry, 29 F.3d 733, 741 (1st Cir. 1994) (upholding guidelines and citing Feeney as requiring that plaintiffs must prove discriminatory purpose); United States v. Bynum, 3 F.3d 769, 774 (4th Cir. 1993) (same).

147. In 1995, the Sentencing Commission concluded that, while crack might pose a "somewhat greater harm to society" than powder cocaine, there was insufficient evidence currently available to support the judgment that crack cocaine poses a substantially greater threat than powder cocaine, and therefore recommended elimination of the 100 to one sentencing ratio. See U.S. SEnIENCING Commin, supra note 142, at 196-98. Congress has not implemented the report's recommendations. See Mary Pat Flaherty \& Joan Biskupic, Missteps Leave Sentence Panel Short of Goals, WASH. Post, Oct. 10, 1996, at A1.

148. Cf. United States v. Then, 56 F.3d 464, 468 (2d Cir. 1995) (Calabresi, J., concurring) (suggesting the constitutional status of the sentencing differential might be affected if Congress were "made aware of both the dramatically disparate impact among minority groups of enhanced crack penalties and of the limited evidence supporting such enhanced penalties" and then failed to equalize the penalties).

149. See, e.g., McCleskey v. Kemp, 481 U.S. 279, 298 (1987) (invoking the Feeney standard of discriminatory purpose in rejecting an equal protection challenge to the death penalty). 
of the laws; ${ }^{150}$ thus, facially neutral domestic violence policies do not violate equal protection unless plaintiffs can show they were adopted at least in part because of their impact on women. ${ }^{151}$ State action concerning sexual assault, child care, and child support is subject to the same standard of review. In all these domains, the state acts in ways that profoundly shape the life circumstances of minorities and women, but the Court has construed the Equal Protection Clause in terms that shield these forms of state action from challenge. Indeed, the Court has interpreted the Equal Protection Clause in terms that seem to invite legislators to act without regard to the foreseeable racial or gendered impact of their actions.

If the Davis/Feeney framework does not find support in psychological or sociological understandings of race and gender bias, perhaps it should be defended on the ground the Court has claimed for it: as warranted by concerns about judicial deference to coordinate branches of government. Of course, this rationale raises a question that implicates concerns of free speech as well as equal protection: whether (or how) constitutional provisions protecting individual liberties should be construed with deference to majoritarian processes. But, I will forego discussion of this larger question in the interests of making a more focused observation about case law mandating different degrees of judicial deference within the Court's equal protection jurisprudence.

In the very same era that the Court adopted the highly deferential Davis/ Feeney framework, it began steadily to increase its scrutiny of affirmative action policies-recently subjecting such policies to strict scrutiny. ${ }^{152}$ Considered together, these two bodies of law create an interesting study in contrasts. When plaintiffs challenge facially neutral policies that have a disparate impact on minorities or women, the Court adopts a highly deferential stance towards a legislature's judgments. But when white plaintiffs challenge affirmative action policies that increase the institutional representation of minority groups, the Court has, with increasing insistence, warned that it will review and restrict the ambit of legislative action. Today, when legislatures employ race-based criteria primarily for the purpose of remedying past discrimination, the Court applies strict scrutiny to such programs, intervening in the legislative process to protect the interests of whites in ways that it will not when plaintiffs challenge legislation having a disparate impact on minorities or women.

Of course, the Court would justify its discrepant response to these two forms of discrimination claims by insisting that it only applies doctrines of heightened scrutiny to facially explicit race- or sex-based state action. But, we might very well ask why this is so. When first adopted, doctrines of heightened scrutiny invalidated many traditional forms of race- and gender-status legisla-

150. For the relevant appellate case law, see Siegel, supra note 4, at 2191 n.270, 2192 n.271.

151. See id. at 2191-92.

152. The Court decided Regents of the University of California v. Bakke, 438 U.S. 265 (1976), only two years after Washington v. Davis, 426 U.S. 229 (1976). There was, however, no majority opinion applying strict scrutiny to affirmative action programs until the late 1980s. See Adarand Constructors, Inc. v. Pena, 115 S. Ct. 2097, 2113 (1995) (applying strict scrutiny to federal affirmative action program); City of Richmond v. J.A. Croson Co., 488 U.S. 469, 493 (1989) (applying strict scrutiny to municipal affirmative action program). 
tion, but regulatory bodies responded by abandoning the use of race- and most forms of gender-specific criteria. ${ }^{153}$ The Court never revised doctrines of heightened scrutiny so that judicial review could detect latent bias in the forms of facially neutral state action that resulted. Thus, today, especially in the area of race, doctrines of heightened scrutiny are functioning primarily as a check on affirmative action programs. By their terms, doctrines of heightened scrutiny do not apply to facial neutral laws like the sentencing guidelines, decisions concerning education and zoning, or policies concerning spousal assault and child support, whose incidence falls primarily on minorities or women. The Court assumes these policies were enacted in good faith-even as it applies "skeptical scrutiny" to policies that attempt to rectify centuries of discrimination against minorities and women.

The Court invokes history to justify applying strict scrutiny to race-conscious remedies, emphasizing, on more than one occasion, that "[ $t]$ he history of racial classifications in this country suggests that blind judicial deference to legislative or executive pronouncements of necessity has no place in equal protection analysis." 154 But the historical narrative the Court invokes to justify its current use of strict scrutiny doctrine is highly abstracted, depicting centuries of racial status regulation as a "history of racial classifications." When the Court presents the history of racial status regulation as a "history of racial classifications," it can equate racial classifications used to promote integration with racial classifications used to promote segregation, and equate regulation seeking to alleviate racial stratification with regulation seeking to perpetuate racial stratification. At the same time, by abstracting the history of racial status regulation into a narrative of "racial classifications," the Court obscures the multiple and mutable forms of racial status regulation that have subordinated AfricanAmericans since the Founding-including the facially neutral forms of state action that, since Reconstruction, have regulated racial status in matters of employment, political participation, and criminal justice. From this highly abstracted standpoint-one that is inattentive to the social meaning of racial status regulation or the various and evolving forms it has assumed over the course of American history-it "makes sense" to apply "skeptical scrutiny" to race-conscious remedies, while reviewing facially neutral regulation deferentially, on the premise that it is enacted in good faith.

Of course, contemporary equal protection law looks quite different from the analytical standpoint of this essay - which does not equate discrimination with "classification," but begins instead from the premise that status-enforcing state action is mutable in form, evolving in rule structure and justificatory rhetoric as it is contested. When considered from this vantage point, the Court's "fidelity" to doctrines of heightened scrutiny can most charitably be characterized as inflexibility - a failure to adapt its practices of review to changing regulatory

153. See, e.g., Siegel, supra note 4, at 2189-91 (illustrating how, during the 1970s, Supreme Court cases mandating heightened scrutiny of sex-based state action prompted the elimination of sex-specific rules from family law, with analysis focusing on the case of domestic violence policies in particular).

154. See Miller v. Johnson, 115 S. Ct. 2475, 2491 (1995) (quoting City of Richmond v. J.A. Croson Co., 488 U.S. 469, 501 (1989)). 
circumstances. The Court adopted doctrines of heightened scrutiny to strike down certain forms of race and gender status regulation dating from the nineteenth century. As we know, doctrines of heightened scrutiny disestablished much of this legislation and prompted state actors to abandon the use of groupbased classifications and traditional status-based rationales in most regulatory contexts, while reserving regulatory use of group-based classifications for remedial purposes (a response in keeping with the normative concerns initially prompting heightened scrutiny). But once equal protection doctrine had produced these changes, the Court did not modify doctrines of heightened scrutiny so that courts could detect race or gender bias in the legal culture that heightened scrutiny produced: a legal culture in which state actors regulate by facially neutral means, and for reasons which they assert to be, and generally understand to be, legitimate and nondiscriminatory. ${ }^{155}$ Instead, the Court adopted a doctrine of discriminatory purpose for reviewing facially neutral regulation that is explicitly premised on the assumption that courts should defer to the work of coordinate branches of government, and which sanctions facially neutral regulation so long as it is justified in terms that do not sound in discredited forms of status-based reasoning. The Court then began to use doctrines of heightened scrutiny to review and restrict race-based remedial regulation-insisting that affirmative action policies could not rectify "societal discrimination" or promote proportional representation or otherwise engage in what some have called "social engineering." 156 (Note how justifications for constitutional restrictions on affirmative action resemble the nineteenth-century claim that civil rights measures should not legislate "social equality.") Thus, today doctrines of heightened scrutiny function primarily to constrain legislatures from adopting policies designed to reduce race and gender stratification, while doctrines of discriminatory purpose offer only weak constraints on the forms of facially neutral state action that continue to perpetuate the racial and gender stratification of American society.

Just as importantly, this body of equal protection doctrine supplies a language and a perceptual framework that shapes popular debates about race and gender equality. The governing equal protection framework identifies raceand gender-conscious remedies as pernicious "discrimination," while deflecting attention from the many ways that the state continues to regulate the social

155. See note 129 supra (discussing scholarship on unconscious gender bias); text accompanying notes 118-129 supra (analyzing how the civil rights revolution prompted changes in the forms of white racial consciousness); see also Flagg, supra note 127 (discussing "transparency" of white racial consciousness in the civil rights era); Lawrence, supra note 127 (discussing persisting forms of unconscious racism that the doctrine of discriminatory purpose does not detect); Siegel, supra note 4, at 2180-81 (describing how the dynamic of preservation-through-transformation can operate even as legal reformers are acting in the "good faith" understanding that they have repudiated inegalitarian elements of a prior status regime).

156. See, e.g., Croson, 488 U.S. at 496-99, 507-08; see also Hopwood v. Texas, 78 F.3d 932, 951 (5th Cir.), cert. denied, 116 S. Ct. 2580 (1996) (invoking relevant language in the Croson opinion, and concluding that "boundless 'remedies' raise a constitutional concern ... that the program was the result of racial social engineering rather than a desire to implement a remedy"); Morris B. Abram, Affirmative Action: Fair Shakers and Social Engineers, 99 HARv. L. REv. 1312, 1313 (1986) (objecting to new generation of "social engineers" in leadership of civil rights movement, who believe that "the government's role [is] to bring about proportional representation"). 
status of minorities and women, thereby constructing discrimination against minorities and women as a practice of the (distant) past. The social position of minorities and women thus appears to be a legacy of past discrimination-or the product of culture, choice, and ability-while the state's continuing role in shaping the life prospects of minorities and women disappears from -view. In important respects, criticism of the Court's decision to apply strict scrutiny to affirmative action policies exacerbates this dynamic. So long as affirmative action dominates debates about the meaning of equal protection, conversation about "discrimination" continues to focus on practices of race- and genderbased classification, obscuring the myriad forms of state action that contribute to the social stratification affirmative action addresses. There is by now a large body of literature criticizing discriminatory purpose doctrine, advancing proposals to modify, or abolish, the governing doctrinal framework. ${ }^{157}$ It is this kind of analysis that needs to inform debates over the application of "heightened scrutiny" if "heightened scrutiny" is to have any sort of meaningful effect on the forms of status-enforcing state action that disestablishment of traditional forms of race and gender status law has produced.

It is not difficult for us to imagine alternatives to the current constitutional framework. Since the early 1970s, the disparate impact doctrines of Title VII have illustrated what a different equal protection framework might look likeone in which courts scrutinized the impact of governmental practices, rather

157. Commentators have argued that the Court has embraced a narrow definition of discriminatory purpose, at odds vith understandings of bias prevalent in law, sociology, and psychology. See, e.g., Flagg, supra note 127, at 980-91 (drawing on empirical studies of unconscious racial bias to criticize discriminatory purpose doctrine); Lawrence, supra note 127 (arguing that the constitutional inquiry must attempt to ascertain unconscious bias in order to eliminate racial prejudice from governmental decisionmaking); David A. Strauss, Discriminatory Intent and the Taming of Brovin, 56 U. CH. L. REv. 935 (1989) (surveying different conceptions of discrimination in the constitutional case law and arguing that the discriminatory intent standard should require a showing of impartiality in government decisionmaking); see also Gayle Binion, "Intent" and Equal Protection: A Reconsideration, 1983 Sup. CT. Rev. $397,444-45$ (surveying early critics of intent doctrine who proposed alternative formulations of the standard). Commentators have also challenged the foundational assumptions of the reigning doctrinal paradigm, arguing that equal protection doctrine should concern itself with the impact of govemmental practices, rather than the mental state of governmental decisionmakers. See, e.g., LAURENCE H. TRIBE, AMERICAN Constituminal LAw $\$ 16-21$, at 1514-21 (2d ed. 1988) (arguing that facially neutral state action should be analyzed in accordance with an antisubjugation principle); Binion, supra, at $447-56$ (advocating heightened scrutiny of state practices with disproportionately disadvantageous impacts); Theodore Eisenberg, Disproportionate Impact and Illicit Motive: Theories of Constitutional Adjudication, 52 N.Y.U. L. REv. 36 (1977) (discussing appropriate roles for impact and motive analysis); Eisenberg \& Johnson, supra note 124, at 1161-62 (discussing a variety of disparate impact standards that commentators have argued should be applied under the Equal Protection Clause); Fiss, supra note 97 (arguing that the Equal Protection Clause should be construed as prohibiting laws and practices that aggravate or perpetuate the subordinate position of a specially disadvantaged group); Flagg, supra note 127, at 991-1005 (advocating a disparate impact rule); Alan David Freeman, Legitimating Racial Discrimination Through Antidiscrimination Law: A Critical Review of Supreme Court Doctrine, 62 MinN. L. REv. 1049 (1978) (criticizing antidiscrimination law on the grounds that it is elaborated from the standpoint of the perpetrator rather than the victim); Randall L. Kennedy, McClesky v. Kemp: Race, Capital Punishment, and the Supreme Court, 101 Harv. L. Rev. 1388, 1419-21, 1424-29 (1988) (criticizing discriminatory purpose doctrine and arguing that racial minorities have a right to be free of racially subordinating practices, even when harms are inflicted "without any intentional design whatsoever"). 
than the mental state of governmental decisionmakers. ${ }^{158}$ Suppose that the Court had decided Davis differently, and that, in some or all regulatory contexts, doctrines of heightened scrutiny now constrained the government from adopting facially neutral policies that significantly contributed to the race and gender stratification of American society; in those contexts where disparate impact analysis applied, the government would have to justify its policies, and show that it lacked feasible, less discriminatory means for achieving its objectives. ${ }^{159}$ Suppose, further, that courts reviewing the justifications for such facially neutral policies were as concerned with the government's duty to govem impartially as they are now concerned with judges' obligations of deference. Such an equal protection framework would not bar all policies that perpetuated race or gender stratification; but it would alter the nature of public conversation about such policies. In such a world, state actors would be required to acknowledge and justify their role in perpetuating forms of race and gender stratification. In a world where governmental actors were regularly called upon to justify the racial and gender consequences of their policy choices, the government's role in perpetuating race and gender inequality would be far more visible than it now is. In such a world, equal protection litigation might move the nation closer to disestablishing historic patterns of race and gender stratification than current constitutional doctrines now do.

Thus, if our legal culture supplies reasons for adopting the prevailing interpretation of equal protection, it also supplies resources for imagining an alternative interpretation of equal protection. In much the same way, the legal culture of nineteenth-century America supplied reasons for adopting Plessy's interpretation of equal protection, as well as the resources for imagining the interpretation of equal protection that Justice Harlan proposed. ${ }^{160}$ In matters of constitutional interpretation, no less than in other spheres of life, the nation makes choices for which it can be held morally accountable. We now regularly condemn the interpretive choices the nation made during the Reconstruction era, but how are we to evaluate our own?

Today, government rarely classifies by race or gender, but it conducts a "war on drugs," regulates education and residential zoning, responds to "sexual assault" and "domestic violence," and makes policy concerning "child care," "family leave," "child support," and the "welfare" of "single-headed house-

158. See Griggs v. Duke Power Co., 401 U.S. 424 (1971) (recognizing disparate impact claim under Title VII); see also Washington v. Davis, 426 U.S. 229 (1976) (reversing lower court decision applying disparate impact analysis to an equal protection claim and holding that plaintiffs challenging facially neutral state action under the Equal Protection Clause must prove that the state acted with discriminatory purpose); text accompanying notes 97-98 supra (discussing period before Davis decision in which lower courts were applying disparate impact analysis to equal protection claims).

159. Cf. TRIBE, supra note $157, \S 16-21$, at 1514-21 (arguing that facially neutral state action should be analyzed in accordance with an antisubjugation principle; "strict judicial scrutiny would be reserved for those government acts that given their history, context, source, and effect, seem most likely not only to perpetuate subordination but also to reflect a tradition of hostility toward an historically subjugated group, or a pattern of blindness or indifference to the interests of that group").

160. See text accompanying notes 62-65 supra (discussing Justice Harlan's dissent in Plessy, and illustrating how it drew upon the understanding of civil rights shared by congressional authors of 1875 Civil Rights Act). 
holds" in ways that often perpetuate, or aggravate, historic patterns of race and gender inequality. We might construe equal protection guarantees to require heightened scrutiny of the justifications for the design and administration of some or all of these facially neutral policies, yet we do not. As we condemn the ways in which past generations of Americans interpreted the meaning of equal protection, we might also consider how future generations of Americans will judge our own.

\section{ConClusion}

History can serve many purposes in law. Perhaps most often, it functions to preserve the authority of the past. But, as Cass Sunstein has observed, equal protection doctrine assumes a distinctive stance toward the past. Rather than turning to the past as a source of authorizing "history and traditions," equal protection doctrine often repudiates traditional practices. ${ }^{161}$ In this area of constitutional law, the nation articulates its identity aspirationally, reasoning about the meaning of federal citizenship in terms that seek to transcend convictions and conventions of the past.

But the repudiation of past practices plays a complex role within equal protection law. This essay revisits the disestablishment of gender and racial status law during the nineteenth century in order to demonstrate that repudiating past practices has both preservative and transformative effects; it facilitates continuity as well as rupture. The act of repudiating past practices can exculpate present practices, if we characterize the wrongs of the past narrowly enough to differentiate them from current regulatory forms.

We can see this dynamic at work in the nineteenth century. The body of constitutional law that disestablished slavery had to define the practice it was repudiating, and, as it did so, it simultaneously legitimated new forms of state action that perpetuated the racial stratification of American society. ${ }^{162}$ We can observe this dynamic at work in the nineteenth century in significant part because we no longer reason in the juridical categories that the Court employed to legitimate segregation. Indeed, we are able to condemn segregation in ways that even its nineteenth-century critics could not, because distinctions among civil, political, and social rights no longer have imaginative force for us.

How then are we to think about the operations of equal protection law today? As I have shown, the body of equal protection law that disestablished segregation simultaneously authorized new forms of status-enforcing state action. But are these new forms of state action "as bad as" the laws that explicitly authorized segregation? I assume that for many readers the answer to this

161. See Cass R. Sunstein, Sexual Orientation and the Constitution: A Note on the Relationship Between Due Process and Equal Protection, 55 U. CH. L. REv. 1161 (1988):

$[O] n$ any view, the Equal Protection Clause is not rooted in common law or status quo baselines, or in Anglo-American conventions. The baseline is instead a principle of equality that operates as a criticism of existing practice. The clause does not safeguard traditions; it protects against traditions, however long-standing and deeply rooted.

Id. at 1174; see also id. at 1163 ("[T]he Equal Protection Clause looks forvard, serving to invalidate practices that were videspread at the time of its ratification and that were expected to endure.").

162. See text accompanying notes $28-78$ supra. 
question is a clear "no." An argument can easily be made that de jure segregation inflicted more harm than the forms of de facto segregation which state action supports today. ${ }^{163}$ But we may draw this conclusion at least in part because we credit an historically contingent and contested interpretation of the Equal Protection Clause. Even critics of discriminatory purpose doctrine are subject to its persuasive force, and so may view facially neutral state action that perpetuates racial stratification as reasonable-or at least, more reasonablethan de jure segregation now seems. We now look to the reasoning of state actors to determine the legitimacy of their actions, even if their actions preserve forms of social stratification that the nation claims, in principle, to denounce.

Our confidence in making this comparative judgment also grows out of our repudiation of old forms of race and gender status regulation. We have now forged something close to a national consensus that these old forms of status regulation were wrong: bad acts animated by "prejudice" that the nation must strive to transcend. But it is precisely this retrospective judgment that helps support the conviction that current forms of state action cannot be half so bad. After all, current forms of state action differ in rule structure, and are adopted for what we now deem to be "legitimate, nondiscriminatory" reasons. It is only as we look to the racial consequences of the war on drugs or the gender consequences of spousal violence policies that we may experience uncertainty in making the comparative judgment. It is important to dwell in this uncertainty before deciding whether we have broken decisively with the past. For if the analysis of this essay is correct, status-enforcing state action always appears more reasonable in the present than it does in retrospect. We may have repudiated segregation in much the way that nineteenth-century Americans repudiated slavery. And while segregation was clearly an advance over slavery, it did not represent progress of the sort in which we now take pride.

Today, no less than in the past, the nation gives reasons for sanctioning practices that perpetuate the race and gender stratification of American society. Will these reasons remain persuasive, or will they one day appear to be insubstantial rationalizations for practices that helped perpetuate historically entrenched relations of inequality? In the nineteenth century, white Americans were entirely confident of their reasons for drawing distinctions between civil and social rights, but how do we judge those distinctions today? Once we

163. But $c f$. Derrick Beli, Faces at the Bottom of the Well: The Permanence of Racism 12 (1992) (arguing that even those achievements of the civil rights movement that "we hail as successful will produce no more than ... short-lived victories that slide into irrelevance as racial patterns adapt in ways that maintain white dominance"); Kimberle Williams Crenshaw, Race, Reform, and Retrenchment: Transformation and Legitimation in Antidiscrimination Law, 101 HARv. L. REv. 1331, 1376-79 (1988) (observing that the "[r]emoval of ... public manifestations of subordination was a significant gain for all Blacks, although some benefited more than others," but concluding that "[r]acial hierarchy cannot be cured by the move to facial race-neutrality" because "[w]hite race consciousness, in a new form but still virulent, plays an important, perhaps crucial, role in the new regime"); Cheryl I. Harris, Whiteness as Property, 106 HARv. L. Rev. 1707, 1753 (1993) ("Brown I's dialectical contradiction was that it dismantled an old form of whiteness as property while simultaneously permitting its reemergence in a more subtle form. White privilege accorded as a legal right was rejected, but de facto white privilege not mandated by law remained unaddressed.... Redressing the substantive inequalities in resources, power, and ultimately, educational opportunity ... was left for another day, as yet not arrived."). 
appreciate that forms of status-enforcing state action we now deem morally reprehensible were once understood as morally defensible, it would seem to follow that we should evaluate the justifications for our current practices with a certain skepticism. We can only make judgments about current practices in the present, without the benefit of hindsight; but we can make such judgments with the understanding that we are actors in, and not beyond, history. Looking back at our predecessors' efforts to disestablish entrenched systems of inequality and recognizing that they sanctioned new forms of status-enforcing state action as they repudiated the old, we might evaluate our own interpretive choices by asking whether current definitions of equality perpetuate this historical dynamic. Current definitions of equality have produced changes in our social practices. But to what extent have these changes in our practices disestablished historically entrenched systems of social stratification? ${ }^{164}$

As this essay demonstrates, testifying to principles of racial equality by insisting that "Plessy was wrong the day it was decided"165 does not increase the likelihood that equal protection doctrine will continue to protect so-called "protected classes," and may well have the opposite effect. Retrospective resolve of this sort does little to address the ways in which the state regulates the social status of minorities and women today. Instead of disowning the past, we would do well to consider how reasonable and principled interpretation of equal protection justified status-enforcing state action in the nineteenth century, and then ask whether it continues to do so in our own time. In short, it is not enough to condemn Plessy a century after the fact. Once we have judged the interpretive choices of our predecessors, it is just as important to reflect on our own acts of interpretive agency: to ask whether we are rationalizing practices that perpetuate historic forms of stratification, as Plessy did. If we ask this question with the kind of skeptical or critical detachment that a historical understanding of our position affords, it is clear that having reasons for our interpretive choices is not sufficient; we must also take responsibility for their historical consequences. From this standpoint, it is not enough to condemn Plessy a century after the fact. We need also to ask ourselves what opinions like Davis and Feeney will look like a century hence.

164. For an argument that this question will always haunt democratic cultures, whose "political ideals seem partly in tension with their social structures," see Jack M. Balkin, The Constitution of Status, 106 YALE L.J. 2313, 2314 (1997) ("The deepest ideals of democracy are in tension with the social world in which all democracies exist and have always existed; for democracies are always begun and carried out in the shadow of older regimes, existing social structures, past misdeeds, and continuing injustices.").

165. Planned Parenthood v. Casey, 505 U.S. 833, 863 (1992) (citing Plessy v. Ferguson, 163 U.S. 537, 552-64 (1896) (Harlan, J., dissenting)). 